\title{
THE ANTI-CHLAMYDIAL ACTIVITY OF DEFENSIN-LIKE PROTEINS
}

\author{
Ph.D. Thesis
}

Emese Petra Balogh MD

Department of Medical Microbiology

and Immunobiology

University of Szeged

Faculty of Medicine

Szeged

2014 


\section{Table of contents}

1. Table of contents

2. Abbreviation list 3

3. Introduction 5

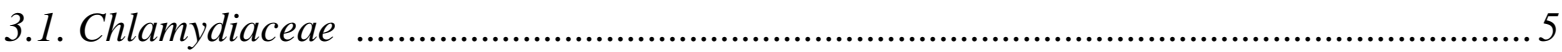

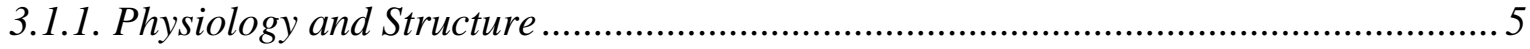

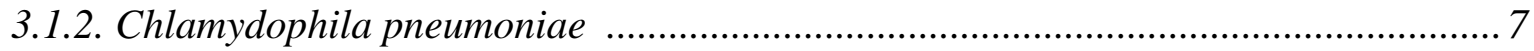

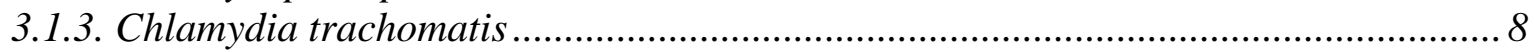

3.2. Chlamydial persistence and the dificulties in the therapy of chlamydial infections ......... 9

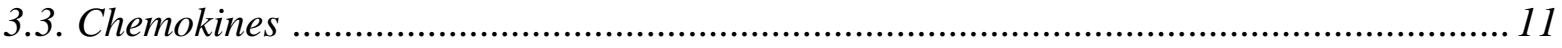

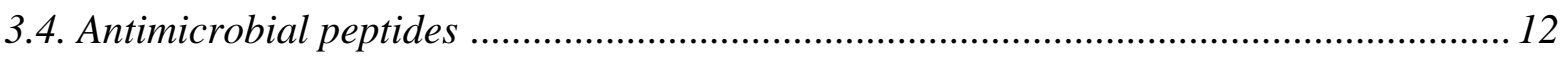

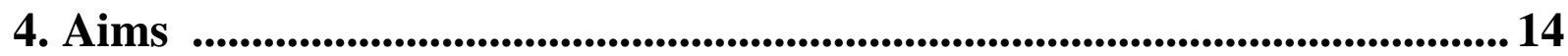

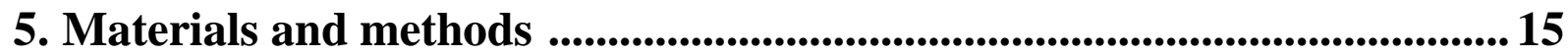

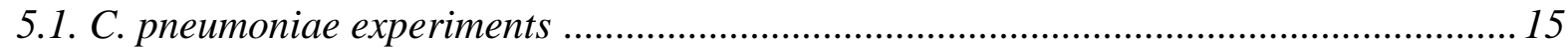

5.1.1. Inoculum preparation and culturing of $C$. pneumoniae from the lungs ................. 15

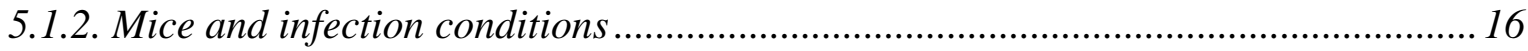

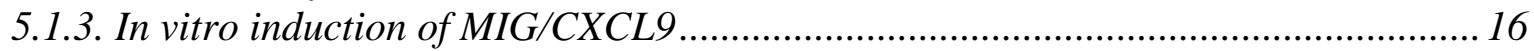

5.1.4. Measurement of the in vitro antibacterial activity of MIG/CXCL9, IP-10/CXCL10

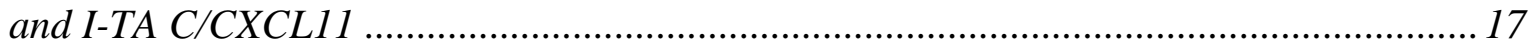

5.1.5. Cytokine and chemokine measurements on the lungs ......................................... 17

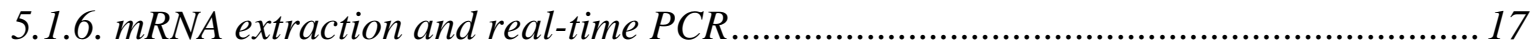

5.1.7. Detection of MIG/CXCL9-binding to Chlamydia EBs by FACS ............................. 18

5.1.8. Far-Western blot assay for identification of MIG/CXCL9-binding C. pneumoniae

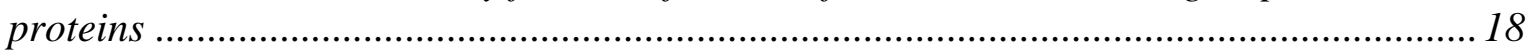

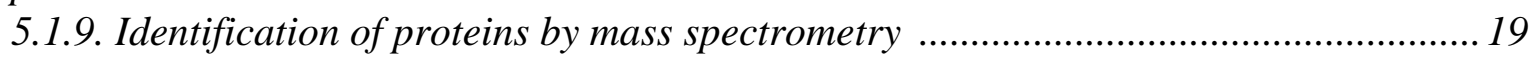

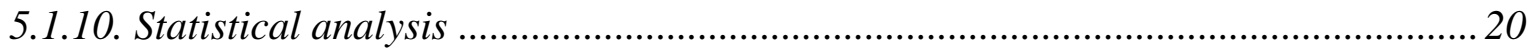

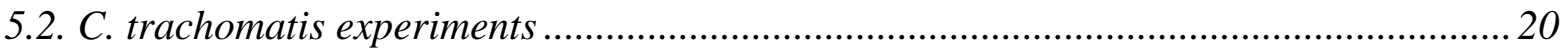

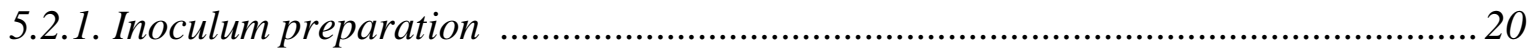

5.2.2. Measurement of in vitro antibacterial activity of NCR peptides .............................. 20

5.2.3. Far-Western blot assay for identification of NCR-binding Chlamydia proteins ...... 21

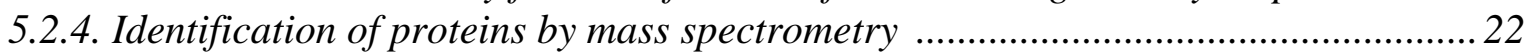

5.2.5. Detection of NCR peptide binding to Chlamydia EBs by FACS ............................... 22 


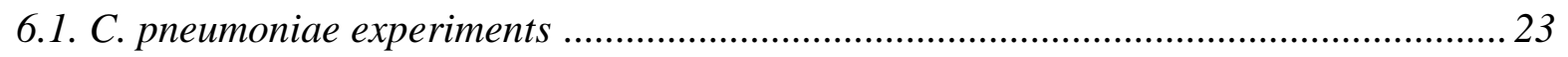

6.1.1. C. pneumoniae infection induces CXC chemokine expression at mRNA and protein

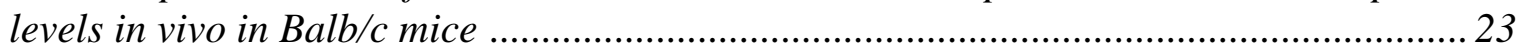

6.1.2. C. pneumoniae induces MIG/CXCL9 in in vitro cell cultures ................................2. 25

6.1.3. Efect of MIG/CXCL9 on C. pneumoniae infectivity ............................................2 27

6.1.4. Identification of the chlamydial ligand responsible for MIG/CXCL9 binding .......228

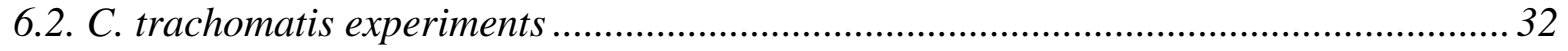

6.2.1. Anti-chlamydial efect of plant peptides................................................................. 32

6.2.2. Identification of the chlamydial ligand responsible for NCR247 binding .................34

6.2.3. FACS analysis for the detection of NCR247 binding to the whole C. trachomatis

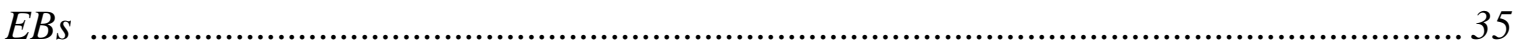

7. Discussion ......................................................................................................37

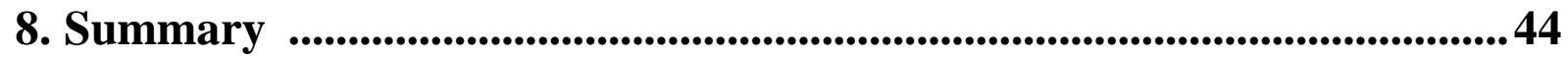

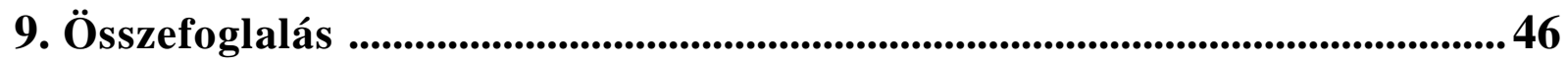

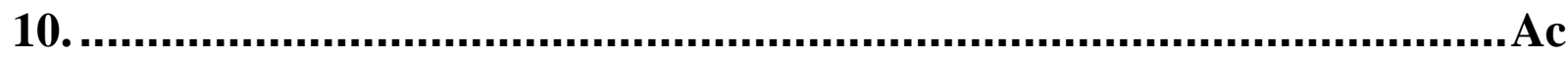

knowledgements .......................................................................................................................48

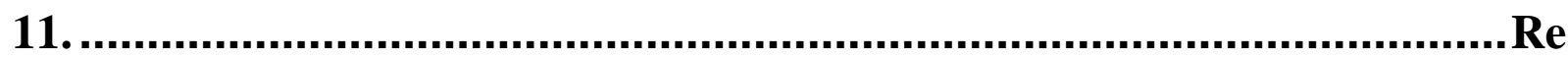

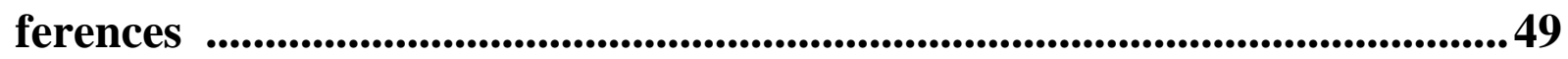




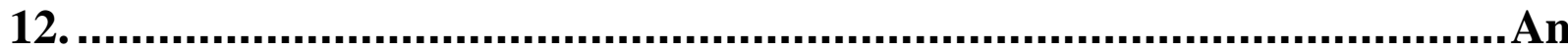

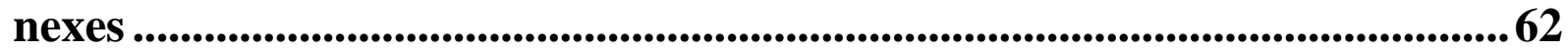




\section{Abbreviation list}

AMPs

ATCC

C. pneumoniae

C. psittaci

C. trachomatis

cDNA

Cys

DTT

EB

ELISA

FACS

FITC

GAG

Gln

HEPES

HRP

IF

IFN

IFU

IL

IP- 10

I-TAC LC-

MSMS

LPS

MIF

MFB

MIG

MOMP antimicrobial peptides

American Tissue Culture Corporation

Chlamydophila pneumoniae

Chlamydophila psittaci Chlamydia

trachomatis complementary

deoxyribonucleic acid

cysteine

dithiothreitol

elementary body

enzyme-linked immunosorbent assay

fluorescence-activated cell sorting

fluorescein isothiocyanate

glycosaminoglycans

glutamine

(2-hydroxyethyl)- 1 -piperazineethanesulfonic acid

horseradish peroxidase

immunofluorescence

interferon

inclusion forming unit

interleukin

interferon-inducible protein- 10 interferon-

inducible T-cell alpha chemoattractant liquid

chromatography-tandem mass spectrometry

lipopolysaccharide

microimmunofluorescence

mouse fibroblast

monokine induced by interferon gamma

major outer membrane protein 
mRNA

MW

NCR

NK

$\mathrm{OmcB}$

PBST

PCR

PE

$\mathrm{RB}$

RNA SD

SDS-PAGE

SPG

TNF messenger ribonucleic acid

molecular weight nodule-

specific cysteine rich

natural killer

outer membrane complex B

phosphate buffered saline with tween

polymerase chain reaction

phycoerythrin

reticular body

ribonucleic acid

standard deviation

sodium dodecyl sulphate polyacrylamide gel electrophoresis

sucrose-phosphate-glutamic acid buffer

tumour necrosis factor 


\section{Introduction}

\subsection{Chlamydiaceae}

The family Chlamydiaceae consists of two clinically important genera, Chlamydia and Chlamydophila, with three species responsible for human disease: Chlamydia trachomatis $(C$. trachomatis), Chlamydophila psittaci (C. psittaci), and Chlamydophila pneumoniae (C. pneumoniae). Other species have been placed into the two genera, but they are uncommon human pathogens.

Chlamydiaceae are obligate intracellular parasites that were once considered viruses because they are small enough to pass through 0.45 Im filters. However, the organisms have the 
regions are found in $C$. psittaci MOMP; in contrast, the $C$. pneumoniae MOMP is homogeneous, and only a single serovar has been described. A second, highly conserved outer membrane protein, OMP 2, is shared by all members of the family Chlamydiaceae. This cysteine-rich protein is responsible for the extensive disulfide cross-links that provide the stability in the EBs (Penttila et al., 2000; Watson et al., 1994).

The replication of Chlamydiaceae occurs within susceptible host cells (Figure 1). The cycle is initiated when the small (300 to $400 \mathrm{~nm}$ ), infectious EBs become attached to the microvilli of susceptible cells, followed by active penetration into the host cell. After they are internalized, the bacteria remain within cytoplasmic phagosomes, where the replicative cycle proceeds. If the outer membrane of the EBs is intact, fusion of cellular lysosomes with the EB-containing phagosome is inhibited, thus preventing intracellular killing. If the outer membrane is damaged or the bacteria are inactivated by heat or coated with antibodies, phagolysosomal fusion occurs with subsequent bacterial killing. Within 6 to 8 hours after entering the cell, the EBs reorganize into the larger (800 to $1000 \mathrm{~nm}$ ), metabolically active RBs. The Chlamydiaceae are energy parasites, because they use the host cell's adenosine triphosphate for their energy requirements. Some strains may also depend on the host to provide specific amino acids. The RBs replicate by binary fission, similar to other bacteria; histological stains can readily detect the phagosome with accumulated RBs, called an inclusion. Approximately 18 to $24 \mathrm{~h}$ after infection, RBs begin to reorganize into smaller EBs, and between 48 and $72 \mathrm{~h}$, the cell ruptures and the infectious bacteria are released (Murray et al., 2009). 


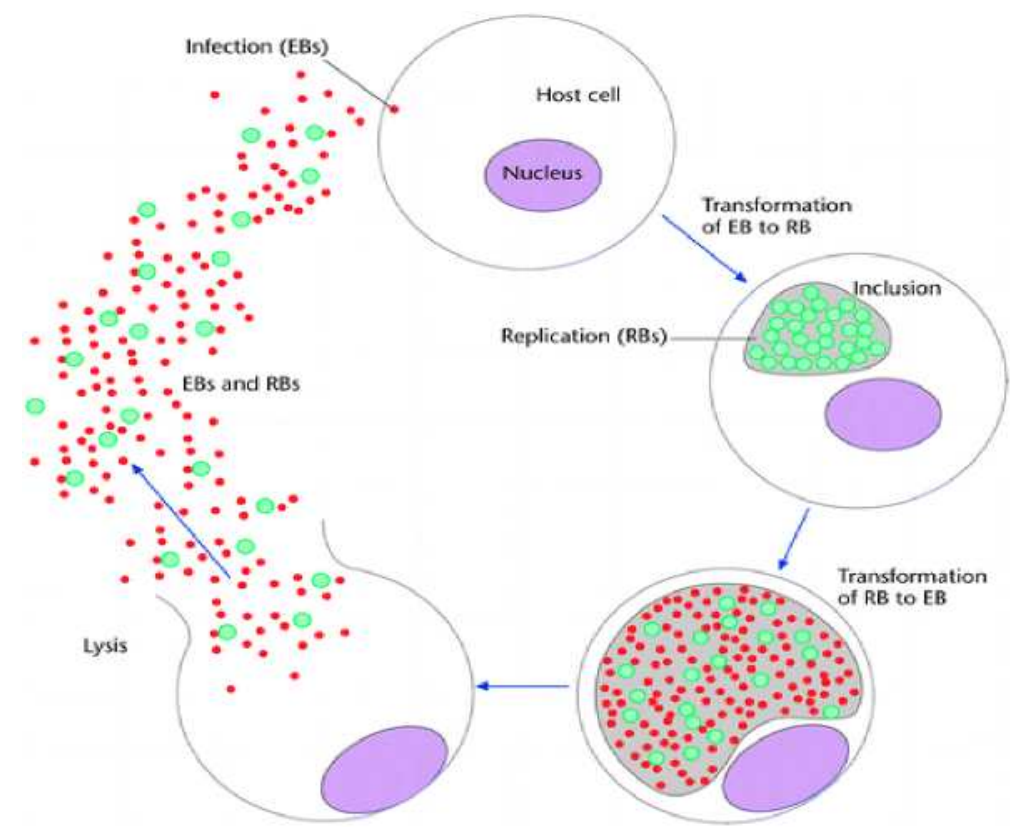

Figure 1. Life cycle of Chlamydiae [www.chlamydiae.com]

\subsubsection{Chlamydophila pneumoniae}

C. pneumoniae is a species of Chlamydophila bacteria that causes $10 \%$ of communityacquired pneumonia cases among adults. Until recently it was known as Chlamydia pneumoniae, and that name is used as an alternate. Previously the pathogen was known as the TWAR agent (Taiwan Acute Respiratory Agent) from the names of the two original isolates Taiwan (TW-183) and an acute respiratory isolate designated AR-39 (Blasi et al., 2009).

C. pneumoniae causes by far the most common human chlamydial infection, with seropositivity in at least $50 \%$ of the general population over the age of 20 in the United States and elsewhere (Kanamoto et al., 1991; Grayston et al., 1992). Although most of the acute infections with $C$. pneumoniae are probably asymptomatic, they may be frequently associated clinically with pneumonia, pharyngitis, sinusitis, and bronchitis (Blasi et al., 2009). Moreover, C. pneumoniae has been suggested to be a risk factor for immune-reactive disorders such as adult onset asthma, reactive arthritis, and the acute chest syndrome of sickle cell anaemia (Hahn et al., 1991; Miller et al., 1991). Chronic infections caused by $C$. pneumoniae have also been linked to the development of heart diseases and atherosclerosis, the diseases which are responsible for the greatest morbidity and mortality in Western civilization (Burian et al., 
2001a; Burian et al 2001b; Rugonfalvi et al., 2002; Heltai et al 2004; Belland et al., 2004). The diagnosis of $C$. pneumoniae infections is difficult. The organisms do not grow in cell lines used for the isolation of $C$. trachomatis, and although $C$. pneumoniae will grow in HEp-2 cell line, this cell line is not used in most clinical laboratories. Detection of $C$. pneumoniae by nucleic acid amplification has long been successful; however, significant interlaboratory variation has been reported among laboratories with diverse experience in the use of these assays (Mahony et al., 1994). Microimmunofluorescence (MIF) test can be considered the only acceptable test for serodiagnosis. The criteria for the diagnosis of acute $C$. pneumoniae infection is a single $\operatorname{IgM}$ titre of $>1: 16$ or a fourfold increase in IgG titer. A single increased IgG titre cannot be appropriately evaluated. Because IgG antibodies do not appear for 6 to 8 weeks after infection, serologic testing has limited value for the diagnosis of an acute infection.

The administration of macrolides (erythromycin, azithromycin, and clarithromycin), doxycycline, or levofloxacin is recommended for the treatment of $C$. pneumoniae infections, although evidence supporting their use is limited. Control of the exposure to C. pneumoniae is rather difficult since the bacterium is ubiquitous (Murray et al., 2009).

\subsubsection{Chlamydia trachomatis}

C. trachomatis has three human serotypes. Serovars Ab, B, Ba, or C cause the trachoma, an infection of the eyes, which is the leading infectious cause of blindness worldwide. Serovariants D-K and L1, L2, L3 cause sexually transmitted diseases, such as urethritis, pelvic inflammatory disease, and ectopic pregnancy (D-K), and lymphogranuloma venereum (LGV; L1-3).

C. trachomatis, especially serovars $\mathrm{D}-\mathrm{K}$, is of great public health significance because of the economic burden of chlamydial infections and the impacts of the untreated (or unsuccessfully treated) cases on human reproduction. Cervicitis and urethritis commonly occur in women, and about $40 \%$ of the untreated cases progress to pelvic inflammatory disease (PID). $20 \%$ of the PID cases results in infertility, while $18 \%$ of the women with this disease experience chronic pelvic pain, and 9\% may suffer an ectopic pregnancy (Shaw et al., 2011).

A prominent survey has been carried out by Washington et al. investigating the direct and indirect healthcare costs of chlamydial infections in men, and the infections and their sequelae 
in women (Washington et al., 1985; Randolph and Washington, 1990). Even though this study demonstrates the chlamydial infections to represent a substantial economic burden, it is still likely to underestimate the full costs of managing chlamydial infections and their consequences. At the individual level, $C$. trachomatis infection can generally be treated effectively with antibiotics, though antibiotic resistance appears to be increasing (Shaw et al., 2011). At the population level, public health control of the infection is rather problematic. With regard to the severe potential consequences of urogenital $C$. trachomatis infection in women, many countries offer screening. A variety of diagnostic methods are available for the detection of asymptomatic infections. Economic investigations suggest that the screening of asymptomatic individuals is a cost-effective strategy. (Malek, 2001)

Vaccination, which is currently unavailable, would be the best way to reduce the prevalence of C. trachomatis infections, as it would be much cheaper and would have a greater impact on controlling C. trachomatis infections worldwide (Hafner et al., 2008, Schautteet et al., 2011, Howie et al., 2011).

Regarding serovars A-C, trachoma is endemic in over 50 countries (Thylefors et al., 1995). Worldwide, over 80 million people have active trachoma, over 7 million have trichiasis (ingrown eyelashes), and over 1 million have blindness due to corneal scarring (Resnikoff et al., 2004, Wright et al., 2008). The prevalence of trachoma varies considerably. For example, in most countries of the Middle-East, Indian sub-continent, South-East Asia, Latin America and Australia, the prevalence of active trachoma has decreased markedly due to the improvements in public health. In contrast, in rural areas of North, East and South Africa trachoma is still hyperendemic. Sadly, active infection with $C$. trachomatis is mostly seen in children around four to six years; the prevalence in the hyperendemic areas can be 70\% (West et al., 2001).

\subsection{Chlamydial persistence and the difficulties in the therapy of chlamydial infections}

Chlamydiae have the ability to cause prolonged and often subclinical infection. In vitro, it can be demonstrated that Chlamydiae can enter a latent state under stressful conditions such as exposure to interferon (IFN)- or certain antibiotics. This persistent form allows $C$. trachomatis to remain dormant in the host cell, resulting in a long-term relationship 
with the host. It is known that serological diagnosis of chronic persistent, latent infections can be somewhat imprecise because of low detectable levels of specific antibodies. It has previously been reported that even very low levels of specific antibodies may be directly associated with a persistent infection. How often persistence occurs in vivo is unknown, but it may serve as an adaptive survival mechanism for the organism.

C. trachomatis infections can be effectively treated with antibiotics that are able to pass through the cell membranes and thus reach the RBs; cyclines, quinolones and macrolides are widely used for this purpose. In the case of pregnant women, amoxicillin is used in the antichlamydial therapy (Guaschino and Ricci, 2002).

Whittington et al. (2001) investigated the chance for therapeutic failures. They noted that 50 of 792 patients with $C$. trachomatis genital tract infections remained infected 42 days after receiving proper doxycycline or azythromycin treatment. The failure of the anti-chlamydial therapy cannot be explained only by re-infection. Several factors were indicated to be associated with infection continuation, such as the age of the patient, the renewal of sexual intercourse, low compliance, and drug pharmacokinetics and availability at the tissue level. However, studies have shown that failure could occur in spite of drug availability.

According to some studies, chlamydial resistance can have a role in therapy failure. Somani et al. published a case report of a pregnant woman and a couple who were respectively infected by $C$. trachomatis serovars $\mathrm{E}$ and $\mathrm{F}$. In the therapy, the minimal concentrations of doxycycline, ofloxacin and azythromycin required to inhibit these patients' isolates were prominently higher than for susceptible control C. trachomatis strains. Based on this work, the authors suggested that certain C. trachomatis strains can bear heterotypic resistance (Somani et al., 2000). This indicates that the chlamydial population contains both susceptible and resistant organisms. Studies on this subject have revealed that only around $1 \%$ of the population is multiresistant (Jones et al., 1990; Lefevre et al., 1997). The mechanism which can be responsible for heterotypic resistance is yet unknown, but persistence can be suggested. C. trachomatis has been reported to adopt an intracellular form that is metabolically less active and thus less sensitive to antibiotics. This results in a long-lasting association between bacteria and their host. 


\subsection{Chemokines}

Chemokines have molecular masses of 8-10 kDa and show approximately 20-50\% sequence homology at the protein level. The proteins also share common gene structures and tertiary structures. All chemokines possess a number of conserved cysteine residues involved in intramolecular disulfide bond formation, which allows chemokines to be grouped into 4 families (Figure 2.): alpha- (CXC), beta- (CC), gamma- (XC) and delta- (CX3C) chemokines, depending on the presence of conserved NH2-terminal cysteine residues (Baggiolini, 2001).

Structure of chemokine classes

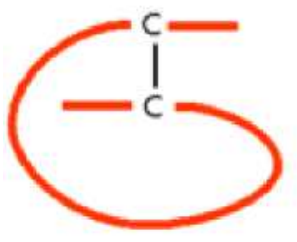

C chemokines

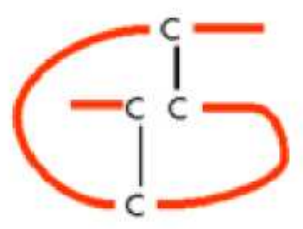

CC chemokines

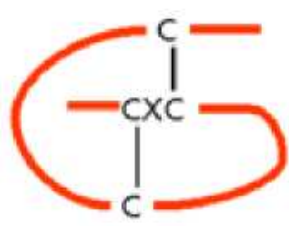

CXC chemokines

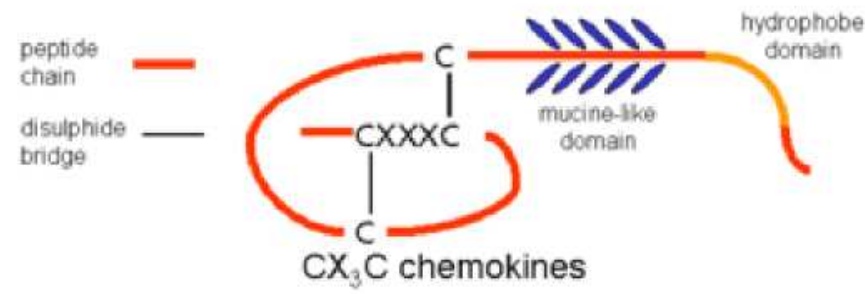

Kohidai, L.

Figure 2. Structure of chemokine classes

[http://www.websters-online-dictionary.org/images/]

The CXC chemokine family is further divided into 2 classes, depending on the presence o absence of an NH2-terminal ELR sequence (Glu-Leu-Arg). The ELR-containing CXC chemokines (e.g. interleukin-8) chemoattract neutrophils, while the non-ELR CXC chemokines chemoattract lymphocytes. The monokine induced by IFN-ם (MIG/CXCL9), the 
epithelial cells and giant cells (Park et al., 2002).

The binding of ligands to the receptors results in the activation and recruitment of the receptor bearing cells to the sites of inflammation. MIG/CXCL9 seems to have a multifaceted role in various immunological processes, such as autoimmune diseases, transplantational immunity, and neuroimmunity. It has also been revealed, that MIG/CXCL9 plays a role in the inhibition of fibrosis and angiogenesis, mainly in pancreatitis, and chronic hepatitis of various origins (Shen et al., 2013; Liang et al., 2012; Sahin et al., 2012). MIG/CXCL9 and other CXC chemokines (IP-10/CXCL10 and I-TAC/CXCL1 1) additionally possess antibacterial activity in vitro (Cole et al., 2001).

Several papers have been published regarding the antimicrobial effects of MIG/CXCL9 against Escherichia coli, Listeria monocyto genes, Streptococcus pyo genes, Streptococcus pneumoniae, Neisseria gonorrheae, Fine goldia magna, Bacillus anthracis, Porphyromonas gingivalis, and Mycobacterium tuberculosis (Cole et al., 2001; Egesten et al., 2007 and 2009; Eliasson et al., 2007 and 2010; Linge et al., 2008; Higaki and Morohashi, 2003; Murdoch, 2008; Karlsson et al., 2007 and 2009; Crawford et al., 2009 and 2010; Jauregui et al., 2013; Bai et al., 2010; Balogh et al., 2011; Handel et al., 2005). However, the function of MIG/CXCL9 in C. pneumoniae infection has not been investigated thoroughly prior to our work. Skwor et al. (2008) found that chemokine protein levels for CCL1 1, CCL8, MIG/CXCL9, and CCL2 were elevated in chronic scarring trachoma when compared with age and sex-matched controls. Mice deficient in the receptor for type I IFNs (IFNAR-/-) exhibited enhanced CD4 T cell recruitment to the cervical tissues, which was associated with an increased expression of MIG/CXCL9 in the genital secretion of IFNAR-/-mice, but not with the expression of CXCL10, which was reduced in the genital secretion of these mice (Nagarajan et al., 2008). In a mouse model after C. trachomatis infection, supernatants from upper genital tract homogenates contained significantly higher levels of MIG/CXCL9, CXCL10, and CCL5 than those in the lower genital tract (Maxion and Kelly, 2001).

\subsection{Antimicrobial peptides}

Antimicrobial peptides (AMPs), natural antibiotics produced by nearly all organisms from bacteria to plants and animals, are crucial effectors of innate immune systems, with different spectra of antimicrobial activity and with the ability to perform rapid killing. To date, more than 800 AMPs have been discovered in various organisms, including 270 in 
plants. It has become clear in recent years that these peptides are able not only to kill a variety of pathogens, but also to modulate immune responses in mammals. However, their modes of action are poorly understood. In some species these peptides serve as the primary antimicrobial defence mechanism, whereas in others they serve as an adjunct to existing innate and adaptive immune systems (Brogden and Brogden, 2011). Cationic AMPs interact with negatively charged microbial membranes and permeabilize the membrane phospholipid bilayer, resulting in lysis and the death of microbes (Powers and Hancock, 2003; Hancock and Rozek, 2002). In view of their rapid and broad-spectrum antimicrobial properties, interest has emerged in AMPs as potential antibiotic pharmaceuticals to combat infections and microbial drug resistance (Hadley and Hancock, 2010; Capparelli et al., 2012).

Most plant AMPs are cysteine cluster proteins. This group includes major plant immunity effectors such as defensins, and also symbiotic peptides, including the nodule-specific cysteine rich (NCR) peptides, which are produced in Medicago-Sinorhizobium meliloti symbiosis and provoke irreversible differentiation of the endosymbiont. The NCR family is composed of about 500 divergent peptides in Medicago truncatula (Mergaert et al., 2003; Alunni et al., 2007; Nallu et al., 2013). Some cationic NCRs have been shown to possess genuine antimicrobial activities in vitro, killing various Gram-negative and Gram-positive bacteria highly efficiently (Tiricz et al., 2013).

The present study was designated to improve our current understanding of the pathological immune response to infection with chlamydiae and to find new natural compounds which have anti-chlamydial activities and might serve as alternative anti-microbial agents. 


\section{Aims}

Our aims were the following

1. to detect whether $C$. pneumoniae can induce the production of CXCL chemokines in vitro and in in vivo mouse model;

2. to investigate the effect of co-treatment with C. pneumoniae and IFN-on the expression of MIG/CXCL9 in different cell types;

3. to study the anti-chlamydial activity of CXCL chemokinesin vitro and to reveal the binding partner of MIG/CXCL9 on Chlamydia EBs;

4. to investigate the anti-chlamydial activity of plant peptides;

5. to find the chlamydial ligand responsible for the binding of NCR proteins. 


\section{Materials and methods}

\subsection{C. pneumoniae experiments}

\subsubsection{Inoculum preparation and culturing of C. pneumoniae from the lungs}

C. pneumoniae strain TWAR CDC/CWL-029 [American Type Culture Collection (ATCC)] and a cardiovascular strain CV6, isolated from an atheroma of a patient with coronary artery disease (Maass et al., 1998), were propagated on HEp-2 cells (Dr Jacobs, National Institute for Biological Standards and Control, London, UK) in Modified Eagle Medium (Sigma, Saint Louis, Missouri, USA), supplemented with $10 \%$ fetal calf serum, $0.5 \%$ glucose, 0.3 mg L-glutamin e, 4 mM HEPES an d 25 gg of gentamycin/ml. Two hours after 


\subsubsection{Mice and infection conditions}

Eight-week-old female Balb/c mice were obtained from the Charles River Laboratory. The mice were fed a regular mouse chow diet ad libitum and housed under biosafety level 2 conditions. Before infection, mice were mildly sedated with an intraperitoneal injection o 2001 of sodium pentobarbital $(7.5 \mathrm{mg} / \mathrm{ml})$. They were then infected intranasally with $5 \times 10^{5}$ IFU of $C$. pneumoniae (CWL029) in 251 of SPG. Uninfected mice were used as controls. After inoculation, 7 mice were anaesthetized and sacrificed on each of days 1, 2, 4, 7, 14 and 28. Sera were taken by cardiac puncture. The lungs were removed, cut up with scissors and then homogenized with seesand (acid purified; Fluka Chemie AG, Buchs, Switzerland) in a mortar with a pestle for $2 \mathrm{~min}$ (each sample). One half of the homogenized lungs was processed for real-time PCR, while the other half was re-suspended in $1 \mathrm{ml}$ of SPG for the detection of viable C. pneumoniae, and for cytokine and chemokine measurements.

All experiments fully complied with the University of Szeged Guidelines for the Use of Laboratory Animals.

\subsubsection{In vitro induction of $M I G / C X C L 9$}

J774A mouse macrophage cells (ATCC) and in-house-prepared mouse fibroblast cultures were grown in 24-well tissue culture plates in Modified Eagle Medium (Sigma) supplemented with $10 \%$ foetal calf serum, $0.5 \%$ glucose, $0.3 \mathrm{mg}$ of L-glutamine/ $\mathrm{ml}, 4 \mathrm{mM}$ HEPES and $25 \mathrm{~g}$ of gentamycin/ml. The semiconfluent tissues were infected with $C$. pneumoniae strain CWL029 or cardiovascular strain CV6 at a multiplicity of infection (m.o.i.) of 0.5 IFU or treated with the same volume of heat-inactivated EBs of the C. pneumoniae strains alone, or in the presence of different concentrations $(10,100$ or $1000 \mathrm{IU} / \mathrm{ml})$ of recombinant IFN-(Millipore, Bedford, Maryland, USA). Untreated cells served as controls. Supernatants of the treated cells were harvested after 24,48 or (in some experiments) 72 h. Samples were centrifuged and stored at $-80{ }^{\circ} \mathrm{C}$ un til use. MIG/CXCL9 concentrations of the samples were determined with the Quantikine mouse CXCL9/MIG kit (R\&D Systems, Minneapolis, USA). 


\subsubsection{Measurement of the in vitro antibacterial activity of MIG/CXCL9, IP-10/CXCL10 and I-TA C/CXCL11}

EBs of $C$. pneumoniae strain CWL-029 $\left(4 \times 10^{4}\right.$ IFU/ml $)$ were incubated with recombinant MIG/CXCL9 (PeproTech London, UK) at various concentrations $(10,5,2.5$ or $1.25 \mathrm{~g} / \mathrm{ml})$ or IP-10/CXCL10 or I-TAC/CXCL1 1 (PeproTech) $(10 \mathrm{~g} / \mathrm{ml})$ in SPG for $2 \mathrm{~h}$ at 37 ${ }^{\circ}$ C. As controls, C. pneumoniae CWL-029 was also incubated either in buffer alone or mixed with heat-treated $(90 \mathrm{C}, 30 \mathrm{~min})$ MIG/CXCL9 $(10 \mathrm{~g} / \mathrm{ml})$. The time course of the antichlamydial effect of MIG/CXCL9 was tested after incubation periods of 0.25, 0.5, 1 and $2 \mathrm{~h}$. To quantitate the anti-chlamydial effects of MIG/CXCL9, IP-10/CXCL10 and I - TAC/CXCL1 1, HEp2 cells were seeded in 24-well tissue culture plates with 13 -mm cover glasses. After 24 h, the confluent cells were infected with MIG/CXCL9-treated C. pneumoniae CWL029 or the controls. After $48 \mathrm{~h}$, the cells were fixed with acetone at $-20{ }^{\circ} \mathrm{C}$ for $10 \mathrm{~min}$. Fixed cells on cover glasses were stained as mentioned above.

\subsubsection{Cytokine and chemokine measurements on the lungs}

The supernatants of the lung homogenates and the sera were clarified by centrifugation ( 5 min, 12 000îg) and were assayed for IFN- content with the OptEIA ELISA set (BD Biosciences Pharmingen San Diego, CA, USA). The concentration of MIG/CXCL9 was determined using Quantikine mouse CXCL9/MIG kit (R\&D Systems). The sensitivities of the IFN- and MIG/CXCL9 measurements lay in the ranges $125-1000 \mathrm{pg} / \mathrm{ml}$ and $31.2-2000 \mathrm{pg} / \mathrm{ml}$, respectively. The clarified supernatants and sera were tested in duplicate in accordance with the manufacturer's instructions.

\subsection{6. $\mathrm{mRNA}$ extraction and real-time PCR}

Total RNA was extracted from the lung suspensions with the TRI Reagent (Sigma). First-strand cDNA was synthesized from $2 \mathrm{~g}$ of RNA by using reverse transcriptase, Superscript III (Invitrogen Carlsbad, Ca, USA) and 20 pM random primer in 201 of reaction buffer. The synthesized first-strand cDNAs were amplified by quantitative real-time PCR, using 20 pM primer pair, with SYBR Green JumpStart ${ }^{\mathrm{TM}}$ Taq ReadyMix $^{\mathrm{TM}}$ (Sigma) in a 
total volume of 201 . Thermal cycling was initiated with a first denaturation step of 5 min at 95 ${ }^{\circ} \mathrm{C}$, followed by 40 cycles of $95{ }^{\circ} \mathrm{C}$ for $10 \mathrm{~s}$ and $60{ }^{\circ} \mathrm{C}$ for $30 \mathrm{~s}$. The mouse MIG/CXCL9specific primers were as follows: MIG/CXCL9 sense 5'-ACG TAG GTT TCG AGA CCA GGG ATT-3', MIG/CXCL9 antisense 5'-CAA CAC CAA GTG TTC TGC CAC CAA-3'; IP10/CXCL10 sense 5'-TGG CTA GTC CTA ATT GCC CTT GGT-3', IP10/CXCL10 antisense 5'-TCA GGA CCA TGG CTT GAC CAT CAT-3'; ITAC/CXCL11 sense 5'-TAC CCG AGT AAC AGC TGC GAC AAA-3', ITAC/CXCL1 1 antisense 5'-TAT GAG GCG AGC TTG CTT GGA TCT-3'. The real-time PCR amplification data were analysed by means of the Roche Molecular Biochemicals LightCycler Software version 3.5. The lowest cycle number at which the various transcripts were detectable, referred to as the threshold cycle $(\mathrm{Ct})$, was compared with that of $\beta$-actin, the difference being referred to as $\mathrm{Ct}$. The relative expression level was given as $2-(\mathrm{Ct})$, where $\quad \mathrm{Ct}=\mathrm{Ct}$ for the experimental sample minus

$\mathrm{t}$ for the control sample.

\subsubsection{Detection of MIG/CXCL9 -binding to Chlamydia EBs by FACS}

Chlamydia EBs ( $\left.1 \times 10^{6} \mathrm{IFU}\right)$ were treated with $10 \mathrm{~g}$ of MIG/CXCL9 containing PBS for $2 \mathrm{~h}$ at $37{ }^{\circ} \mathrm{C}$. After washing, the cells were stained with phycoerythrin(PE)-labelled antiMIG/CXCL9 polyclonal antibody (R\&D Systems) for $30 \mathrm{~min}$ at $4{ }^{\circ} \mathrm{C}$. As controls, untreated and unstained, and untreated PE-labelled anti-MIG/CXCL9-stained cells were used. Cells were analysed with FACS StarPlus (Becton Dickinson) device.

\subsubsection{Far-Western blot assay for identification of MIG/CXCL9-binding C. pneumoniae proteins}

Concentrated C. pneumoniae CWL-029 EBs (1,75x 105 IFU) (prepared as described earlier) and a mock preparation were heated at $95{ }^{\circ} \mathrm{C}$ for $5 \mathrm{~min}$ in sample buffer, and polyacrylamide gel electrophoresis was performed (Laemmli, 1970). The proteins were separated by $10 \%$ SDS polyacrylamide gel in duplicate, and half of the gel carrying the separated proteins of the $C$. pneumoniae or the mock samples was blotted onto a polyvinylidene difluoride membrane (SERVA, Heidelberg, Germany). The membrane was blocked overnight at $4{ }^{\circ} \mathrm{C}$ with PBS containing 5\% skimmed milk and $0.05 \%$ Tween 20 . The 
membrane was probed with a buffer [1\% bovine serum albumin in PBS with $0.05 \%$ Tween 20 (PBST)] containing $10 \mathrm{~g} / \mathrm{ml} \mathrm{MIG/CXCL9} \mathrm{(PeproTech)} \mathrm{for} 2 \mathrm{~h}$. After washing 3 times with PBST, the filter was incubated with HRP-conjugated anti-MIG/CXCL9 IgG (R\&D Systems). A control lane with separated $C$. pneumoniae EBs was also incubated with HRP-conjugated anti-MIG/CXCL9 without prior treatment with MIG/CXCL9. Following 3 further washings the colour was developed by using diaminobenzidine tetrahydrochloride (Sigma) with hydrogen peroxide in $10 \mathrm{mM}$ Tris at $\mathrm{pH}$ 7.5. The second half of the gel with the separated proteins of the C. pneumoniae or the mock preparation was stained with Coomassie blue (Rosenfeld et al., 1992).

\subsubsection{Identification of proteins by mass spectrometry}

The gel slices containing the polypeptides of the concentrated $C$. pneumoniae EBs corresponding to proteins showing MIG/CXCL9 positivity in the blotting assay were cut out from the gel and analyzed by mass spectrometry. Briefly, protein bands were diced and washed with $25 \mathrm{mM} \mathrm{NH} 4 \mathrm{HCO}_{3}$ in $50 \%(\mathrm{v} / \mathrm{v})$ acetonitrile/water. Disulphide bridges were reduced with dithiothreitol (DTT), and free sulphydryls were alkylated with iodoacetamide. Proteins were digested with modified porcine trypsin (Promega Madison, WI, USA) for $4 \mathrm{~h}$ at $37^{\circ} \mathrm{C}$. Samples were analyzed on LC-MSMS (liquid chromatography-tandem mass spectrometry) instruments. The LC-MSMS raw data were converted into a Mascot generic file with Mascot Distiller software (v2. 1.1.0). The resulting peak lists were searched by using the Mascot Daemon software (v2.2.2) against the NCBI non-redundant database without species restriction (NCBInr 20080718,6833826 sequences). Monoisotopic masses with a peptide mass tolerance of $\pm 0.6 \mathrm{Da}$ and a fragment mass tolerance of $1 \mathrm{Da}$ were submitted. Carbamidomethylation of Cys was set as a fixed modification and acetylation of protein $\mathrm{N}$ - termini, methionine oxidation, and pyroglutamic acid formation from peptide N-terminal Gln residues were permitted as variable modifications. Acceptance criteria were at least 2 individual peptides with a minimum peptide score of 55 per protein. 


\subsubsection{Statistical analysis}

Statistical analysis of the data was carried out with GraphPad Prism 5 software, using the Wilcoxon-Mann-Whitney two-sample test. Differences were considered significant at $p<0.05$.

\subsection{C. trachomatis experiments}

\subsubsection{Inoculum preparation}

C. trachomatis Serovar D (ATCC $-\mathrm{VR}-885^{\mathrm{TM}}$ ) was propagated on HeLa cells as described earlier (Caldwell et al., 1981). The partially purified and concentrated EBs were aliquoted and stored at $-80{ }^{\circ} \mathrm{C}$ until use. A mock preparation was prepared from an uninfected HeLa cellD monolayer processed in the same way as the infected cells. The titre of the infectious EBs was determined by indirect immunofluorescence assay. Serial dilutions of the EB preparation were inoculated onto tissue culture monolayers and, after a 48-h culture, cells were fixed with acetone and stained with murine monoclonal anti-Chlamydia LPS antibody (AbD Serotec, Oxford, UK) and FITC-labelled secondary anti-mouse IgG (Sigma). The number of inclusions was counted under a UV microscope, and the titre was expressed in inclusion forming units $/ \mathrm{ml}$ (IFU/ml).

\subsubsection{Measurement of in vitro antibacterial activity of NCR peptides}

First, the toxicity of the NCR peptides was tested on non-infected HeLa cells in the highest concentration $(10 \mathrm{~g} / \mathrm{ml})$ used during our experiments. The toxic peptides were excluded from the further experiments.

EBs of $C$. trachomatis D (4 î $\left.10_{4} \mathrm{IFU} / \mathrm{ml}\right)$ were incubated with chemically synthesized mature NCR030 (AFLPTSRNCITNKDCRQVRNYIARCRKGQCLQSPVR $\quad \mathrm{pI}=10,37$ ); NCR044 (AFIQLSKPCISDKECSIVKNYRARCRKGYCVRRRIR $\quad \mathrm{pI}=10,32) ; \quad$ NCR055 (VNDCIRIHCKDDFDCIENRLQVGCRLQREKPRCVNLVCRCLRR $\quad \mathrm{pI}=9,21$ ); $\quad$ NCR095 $\begin{array}{ll}\text { (ELVCDTDDDCLKFFPDNPYPMECINSICLSLTD } & \text { pI=3,62); NCR1 } 37\end{array}$ $\begin{array}{ll}\text { (MTLRPCLTDKDCPRMPPHNIKCRKGHCVPIGKPFK } & \text { pI=9,7); } \quad \text { NCR1 } 68\end{array}$ (YPFQECKVDADCPTVCTLPGCPDICSFPDVPTCIDNNCFCT pI=3,61); NCR1 69 
(EDIGHIKYCGIVDDCYKSKKPLFKIWKCVENVCVLWYK (ITISNSSFGRIVYWNCKTDKDCKQHRGFNFRCRSGNCIPIRR (MKNGCKHTGHCPRKMCGAKTTKCRNNKCQCVQL (RNGCIVDPRCPYQQCRRPLYCRRR

$$
\mathrm{pI}=10,15) \text {; }
$$

$\mathrm{pI}=8,45) ; \quad$ NCR 183 $\mathrm{pI}=10,1) ; \quad$ NCR192 $\mathrm{pI}=9,54)$;

or
NCR247

NCR280

(MRVLCGRDGRCPKFMCRTFL pI=9,8) (Proteogenix Oberhausbergen, France) at various concentrations $(10,5,2.5$, or $1.25 \mathrm{gg} / \mathrm{ml})$ in sucrose-phosphate-glutamic acid buffer (SPG) for 
7.5. The second half of the gel with the separated proteins of $C$. trachomatis or the mock preparation was stained with PageBlue Protein Staining Solution (Fermentas).

\subsubsection{Identification of proteins by mass spectrometry}

The gel slices containing the polypeptides of the concentrated $C$. trachomatis EBs corresponding to proteins exhibiting NCR247 positivity in the blotting assay were cut ou from the gel and analyzed by mass spectrometry. The proteins were identified as mentioned above in section 5.1.9.

5.2.5. Detection of NCR peptide binding to Chlamydia EBs by FACS Chlamydia EBs (1 î 106 IFU) were treated with 1 gg of FIT 


\section{Results}

\subsection{C. pneumoniae experiments}

\subsubsection{C. pneumoniae infection induces CXC chemokine expression at mRNA and protein}

levels in vivo in Balb/c mice

To investigate the production of ELR-negative CXC chemokines in $C$. pneumoniae infection, Balb/c mice were inoculated intranasally withC. pneumoniae CWL-029. On day 1, 2, 4, 7, 14 or 28 after infection, the mice were sacrificed and the lungs were collected for the determination of $C$. pneumoniae titres, MIG/CXCL9, IP-10/CXCL10 and I-TAC/CXCL1 1 mRNA and MIG/CXCL9 and IFN-protein in the individual lungs.

In previous studies, culturable $C$. pneumoniae was demonstrated 14 days after primary infection in Balb/c mouse lungs (Kis et al., 2008). In our experiment, the infectious bacterial titres were below the level of detectability at $24 \mathrm{~h}$ after infection, but had increased to $5.21 \times 10^{4}$ IFU/lung by day 2 . The peak titre of $C$. pneumoniae was measured on day 7 , at $1.8 \times 10^{6} \mathrm{IFU} / \mathrm{lung}$, and on day 14 after infection, the titre had decreased to 6.15x 103 IFU/lung (Figure 3A).

The expression of MIG/CXCL9 mRNA was increased as early as on day 1, but the highest level of expression (156-fold) was detected on day 7 after infection (Figure 3B). The expression of IP-10/CXCL10 and I-TAC/CXCL1 1 mRNA was observed from the first day, but, in contrast with MIG/CXCL9 expression, peaked on day 4 at 85-fold and 579-fold, respectively (Figure 3C,D). The kinetics of production of MIG/CXCL9 protein correlated with the mRNA expression: it was increased from day 1, with the highest concentration on day 7 (Figure 3E). MIG/CXCL9 was also detected in the sera on days 7 and $14(360 \pm 124 \mathrm{pg} / \mathrm{ml}$ and $798 \pm 252 \mathrm{pg} / \mathrm{ml}$, respectively). The concentration of IFN- , the main in ducer of MIG/CXCL9 expression, was increased in the lungs during the infection, with a peak level of $12.5 \mathrm{ng} / \mathrm{ml}$ on day 7 (Figure 3F). 

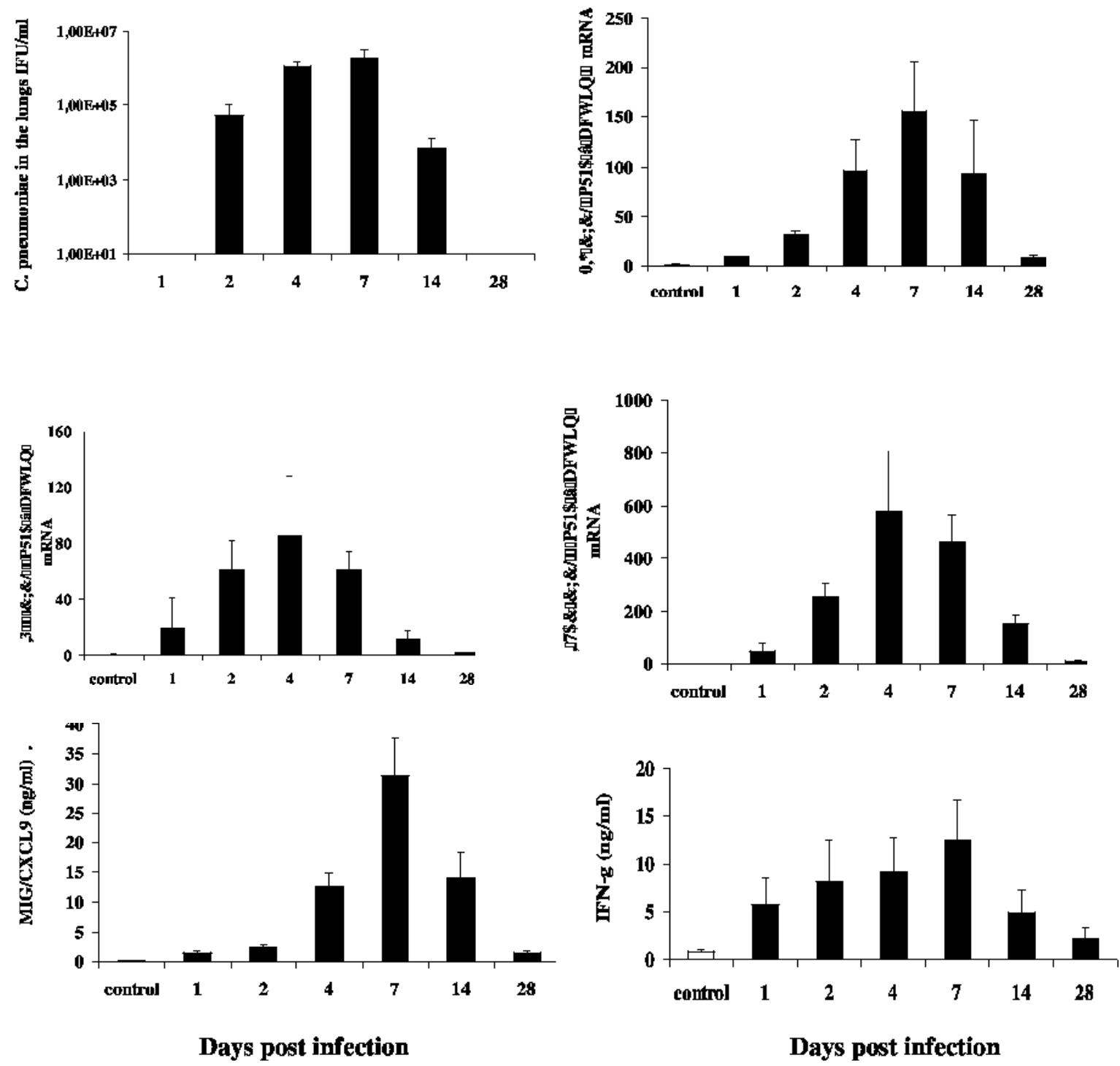

Figure 3. (A) Recovery of culturable C. pneumoniae from the lungs of mice after C. pneumoniae CWL-029 infection. Lung homogenates were inoculated onto HEp-2 cell monolayers and chlamydial inclusions were detected by indirect immunofluorescence, using LPS-specific monoclonal and FITC-labelled secondary antibodies. Expression of MIG/CXCL9 (B), IP-10/CXCL10 (C), and I-TAC/CXCL1 1 (D) in the lungs of infected mice. Total RNA extracted from the lungs was analysed by quantitative real-time PCR with the use of specific primers. Data are normalized for $B$-actin RNA content and plotted as fold change over the results for uninfected mice. IFN- (E) and MIG/CXCL9 (F) production in the lungs of mice infected with C. pneumoniae. Lung homogenates were tested by using IFN- and MIG/CXCL9 ELISA kits according to the manufacturer's instructions. Bars denote 
means and SDs of the results on 7 mouse lungs. 


\subsubsection{C. pneumoniae induces MIG/CXCL9 in in vitro cell cultures}

To clarify whether $C$. pneumoniae is capable of inducing MIG/CXCL9 production in vitro, J774A mouse macrophage cells and mouse fibroblast tissue cultures were infected with $C$. pneumoniae CWL-029 strain, and the supernatants of the cells were tested by MIG/CXCL9-ELISA. After 24 h, no MIG/CXCL9 production was observed in either case (Figure 4A). However, C. pneumoniae induced MIG/CXCL9 secretion by the mouse fibroblasts from day 2 of in fection $(122.7 \pm 22.3 \mathrm{pg} / \mathrm{ml}$ ) (Figure 4B), and J774A cells produced MIG/CXCL9 from day 3 after infection $(156.9 \pm 56.7 \mathrm{pg} / \mathrm{ml})$ (data not shown). The heatinactivated Chlamydia preparation also induced the production of MIG/CXCL9, at a level comparable to that for viable Chlamydia in both cell lines. During in vivo infection with $C$. pneumoniae, a large quantity of IFN-the main inducer of MIG/CXCL9) was detected in the mouse lungs. When the influence of IFNon $C$. pneumoniae-induced MIG/CXCL9 production was investigated in in vitro cultures, co-treatment with different quantities of recombinant mouse IFN- (10, 100 or $1000 \mathrm{U} / \mathrm{ml})$ and C. pneumoniae at a m.o.i. of 0.5 caused a dose-dependent increase in MIG/CXCL9 secretion in both cultures from day 1. Cotreatment of the mouse fibroblasts with C. pneumoniae and 10, 100 or $1000 \mathrm{U} / \mathrm{ml}$ of IFN-caused 51.8-, 27and 25.8-fold increases in MIG/CXCL9 production, respectively, after $24 \mathrm{~h}$ relative to that evoked by treatment with the same quantities of IFN- alone. The enhancement of the secretion of MIG/CXCL9 was similar when the co-treatment was carried out with heatinactivated C. pneumoniae and different quantities of IFN-10, 100 or $1000 \mathrm{U} / \mathrm{ml}$ ): 75-, 31.5- and 25.8fold increases were observed after $24 \mathrm{~h}$ as compared with the increase induced by the different quantities of IFN- alone. Co-treatment of the J774A cells with C. pneumoniae and 10, 100 or $1000 \mathrm{U} / \mathrm{ml}$ of IFN- led to 21.6-, 7.4- and 10.8-fold increases in MIG/CXCL9 production, respectively, after $24 \mathrm{~h}$ in comparison with that evoked by the treatment with the same quantities of IFN-alone. The elevation of the secretion of MIG/CXCL9 was also more pronounced, as in the case of the elevation of mouse fibroblasts when the cotreatment was carried out with heat-inactivated $C$. pneumoniae and different quantities of IFN-10, 100 or $1000 \mathrm{U} / \mathrm{ml}$ ): 25.3-, 8.7- and 13.3-fold increases, respectively, after $24 \mathrm{~h}$ relative to the data for IFN-alone. Under all of the conditions mentioned above, the mouse fibroblasts produced significantly more MIG/CXCL9 than did the J774A $(p<0.05$; 
Figure 4A,B). Similar results were seen under the conditions described above in both cell cultures after $48 \mathrm{~h}$ (Figure 4B).

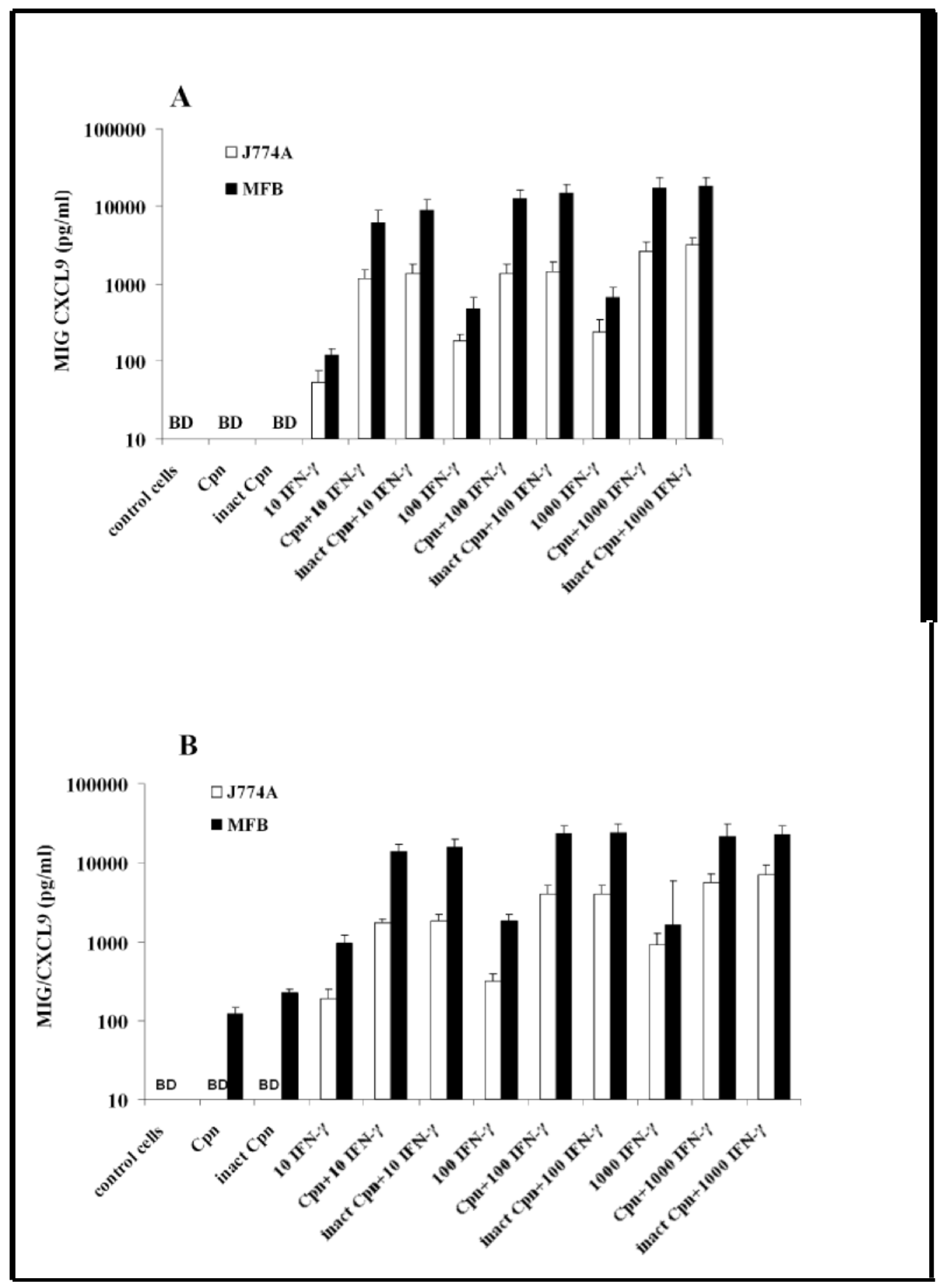

Figure 4. C. pneumoniae-induced MIG/CXCL9 production in J774A and mouse fibroblast (MFB) cells in the presence of IFN-. The cells were grown in 24-well tissue culture plates. The semi-confluent tissues were 
infected with C. pneumoniae strain CW-L029 at a m.o.i. of 0.5 IFU, or were treated with the same amount of heatinactivated $C$. pneumoniae alone, or in the presence of different quantities of IFN- (10, 100 or $1000 \mathrm{U} / \mathrm{ml})$. Untreated J774A and MFB cells served as controls. Supernatants of the 3 biological replicates were taken afte 24 (A) and 48 (B) h. Samples were clarified by centrifugation, and the MIG/CXCL9 concentrations in th samples were detected with the ELISA kit accordingto the manufacturer's instruction. BD: below detectability All the data are representative of three separate experiments; SDs are shown. MFB cells produced a significantl higher level of MIG/CXCL9 than J774A cells in all combinations and at both time points $(p<0.05)$.

A separate experiment revealed that the viable cardiovascularC. pneumoniae strain CV6 and its inactivated form also induced MIG/CXCL9 production in the mouse fibroblasts $(156 \pm 34$ and $187 \pm 67 \mathrm{pg} / \mathrm{ml}$, respectively) after $48 \mathrm{~h}$ and also in the J774A cells $(124 \pm 35$ and $141 \pm 47 \mathrm{pg} / \mathrm{ml}$, respectively) after $72 \mathrm{~h}$ (data not shown).

\subsubsection{Effect of MIG/CXCL9 on C. pneumoniae infectivity}

To determine whether MIG/CXCL9 has anti-chlamydial activity, in vitro bactericidal tests were carried out. Co-incubation of $C$. pneumoniae with recombinant mouse MIG/CXCL9 demonstrated a dose-dependent antibacterial activity of MIG/CXCL9 againstC. pneumoniae. At a MIG/CXCL9 concentration of $10 \mathrm{~g} / \mathrm{ml}$, the number of viable $C$. pneumoniae inclusions was reduced by $98.4 \%$, and at the lowest MIG/CXCL9 concentration tested $(1.25 \mathrm{~g} / \mathrm{ml})$ a reduction of $79 \%$ was detected. The heat-treated recombinant MIG/CXCL9 did not exert an antichlamydial effect (Figure 5A). The experiments relating to the time course of the antibacterial effect of MIG/CXCL9 demonstrated a significant reduction (50\%) in the number of viable Chlamydia inclusions after a 15-min co-incubation of MIG/CXCL9 and the Chlamydia EBs (Figure 5B). No anti-chlamydial effect was observed when other ELR-negative chemokines, IP10/CXCL10 and I-TAC/CXCL1 1, were co-incubated with C. pneumoniae at a concentration of $10 \mathrm{~g} / \mathrm{ml}$ (data not shown). 


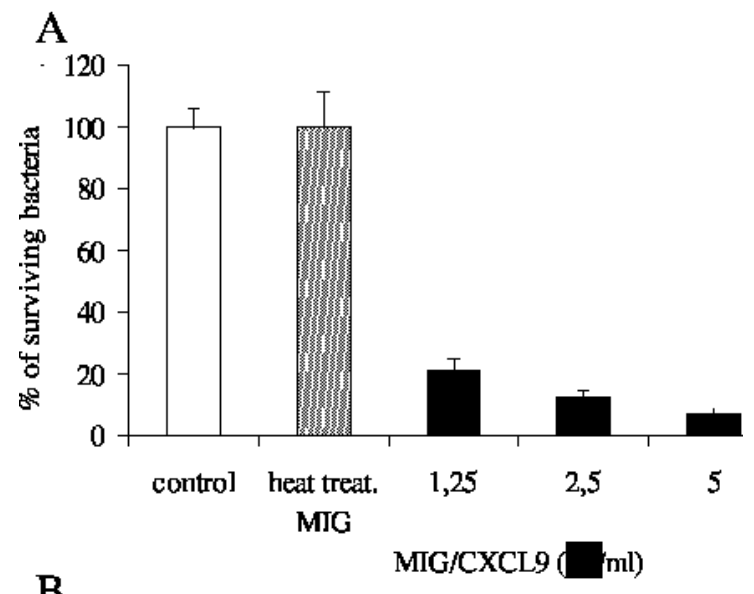

B

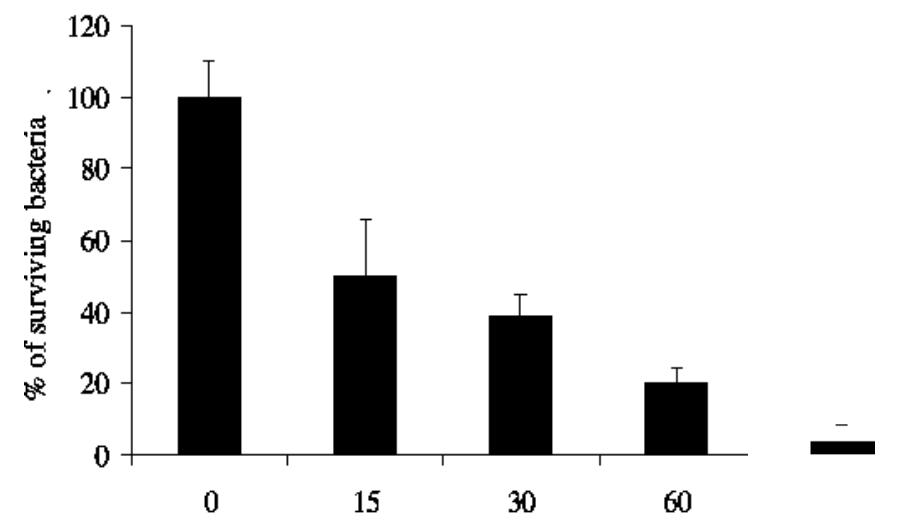

Figure 5. Concentration and time dependences of the anti-chlamydial effect of MIG/CXCL9. C. pneumoniae CWL-029 at 4X10 $0^{4} \mathrm{IFU} / \mathrm{ml}$ was incubated with different quantities of recombinant MIG/CXCL9 for $2 \mathrm{~h}$ at $37^{\circ} \mathrm{C}$ (A). C. pneumoniae was co-incubated with MIG/CXCL9 $(5 \mathrm{~g} / \mathrm{ml})$ for 0, 15, 30, 60 or $120 \mathrm{~min}(\mathrm{~B})$. The infectivity of the MIG/CXCL9-treated C. pneumoniae was determined by inoculating the mixture onto confluent HEp-2 cells on cover glasses. After a 24-h incubation, the fixed cells were stained with anti-chlamydia LPS antibody and the number of inclusions was counted under a UV microscope. All the data are representative of three separate experiments.

\subsubsection{Identification of the chlamydial ligand responsible for MIG/CXCL9 binding}

The concentrated $C$. pneumoniae EB preparation and the mock control preparation were separated by SDS-PAGE. After blotting, the membranes were probed with recombinant mouse MIG/CXCL9 and incubated with HRP-conjugated anti-MIG IgG. The control lane with Chlamydia EBs was stained with HRP-conjugated anti-MIG/CXCL9 IgG without incubation with MIG/CXCL9. The recombinant mouse MIG/CXCL9 was bound to 60 and 30 
$\mathrm{kDa}$ protein bands in the Chlamydia lysate (Figure 6A). The recombinant mouse MIG/CXCL9 did not react with the mock lysate, and the Chlamydia EB lysate did not react with the HRPconjugated anti-MIG/CXCL9. The gel slices containing the corresponding polypeptides of the concentrated $C$. pneumoniae EBs associated with the recombinant mouse MIG/CXCL9 were cut out from the gel and analysed by liquid chromatography-tandem mass spectrometry (LCMSMS) in the Biological Research Centre, Hungarian Academy of Sciences, Szeged. Three kinds of chlamydial proteins were indicated by LC-MSMS and confirmed by post source decay analysis. The identified proteins included two forms of the $60 \mathrm{kDa}$ cysteine-rich protein (also named OmcB/Omp2), which has been shown to be a chlamydial EB surface component to which heparin molecules can anchor (Stephens et al., 2001). Besides the $60 \mathrm{kDa}$ whole form, a $30 \mathrm{kDa}$ truncated form of the $60 \mathrm{kDa}$ cysteine-rich protein $(\mathrm{OmcB} / \mathrm{Omp} 2)$ was identified. A third $60 \mathrm{kDa}$ protein was identified as the putative GroEL protein of $C$. pneumoniae (Table 1) (Figure 6B).

\begin{tabular}{|c|c|c|c|c|c|c|}
\hline Band & $\begin{array}{c}\text { Name of the } \\
\text { protein }\end{array}$ & Protein ID & MW(Da) & $\begin{array}{c}\text { Sequence } \\
\text { Coverage (\%) }\end{array}$ & $\begin{array}{c}\text { Number of } \\
\text { unioue } \\
\text { peptides }\end{array}$ & $\begin{array}{r}\text { Protein } \\
\text { Score }\end{array}$ \\
\hline \multirow[t]{2}{*}{1} & $\begin{array}{c}60 \mathrm{kDa} \\
\text { chaperonin } \\
\text { (Putative GroEL } \\
\text { protein } C . \\
\text { pneumoniae) }\end{array}$ & $\begin{array}{c}\text { P3 } 1681 \\
\text { AAA23 } 126\end{array}$ & 58204 & 21 & 14 & 915 \\
\hline & $\begin{array}{c}60 \mathrm{kDa} \text { cysteine- } \\
\text { rich OMP } C \\
\text { pneumoniae } \\
\text { (OmcB/ OMP2) }\end{array}$ & $\begin{array}{l}\text { P23700 } \\
\text { NP_224753 }\end{array}$ & 59719 & 6 & 3 & 242 \\
\hline 2 & $\begin{array}{c}\text { Part of outer } \\
\text { membrane protein } \\
2(\text { OmcB/OMP }) \\
\text { C. pneumoniae } \\
(\sim 30 \mathrm{kDa})\end{array}$ & $\begin{array}{l}\text { Q9S6B3 } \\
\text { AAD20337 }\end{array}$ & 42273 & 6 & 3 & 172 \\
\hline
\end{tabular}

Table 1. LC-MS/MS analysis of proteins combined with MIG/CXCL9 identified by SDS-PAGE separation. Band numbers refer to the gel bands shown in Figure 6. MW is calculated for the full sequence listed in the database and may not reflect the actual size of the protein. 
B. putative GroEl protein [c. pneunoniae]

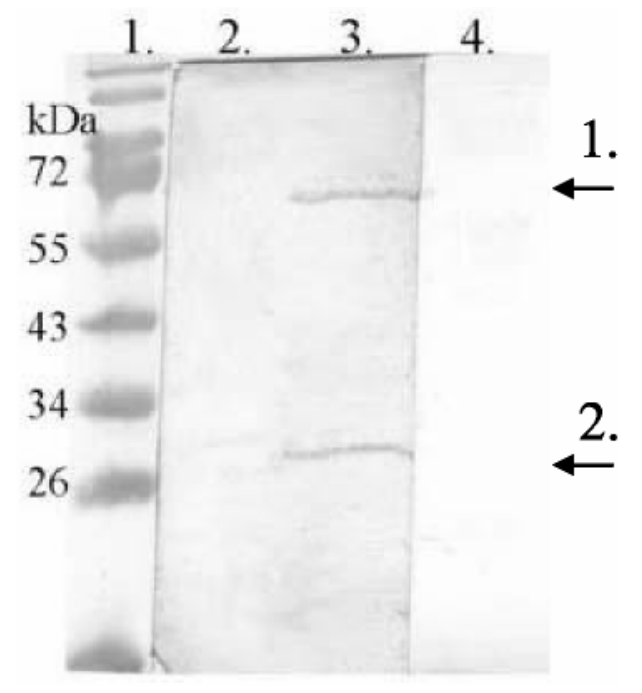

1 MAMKIKMNE EARKKIHKGV KTLAEAVKNT LGPKGRHVVI DKSFGSPQVT

51 KDGVTVAKEI ELEDKHENWG AQLVKEVASK TADKAGDGTT TATVLAEAIY 101 SEGLRNVTAG ANPYDLKRGI DKWVKVVVDE LKRISKPVOH HKEI AOVATI 151 S ANND SEIGN LI AEAHEKUG KNGSITVEE Aू KGETVLDW EGIFFHRGYL 201 SSYFSTNPET QECVLEDALI LIYDKKISGI KDFLPVLQQV AESGRPLLI I 251 AEEIEGEALA TLWNRLRAG FRVCAVKAPG FGDRRKAIIE DIAIL TGGQL 301 VSEELGIKLE MTTLALLGKA KKVIVTKEDT TIVEGLGNKP DIQARCDNIK 351 KQIEDSTSDY DKEKLQERLA KLSGGVAVIR VGAATEIFMK EKKDRVDDAQ 401 HATIAAVEEG ILPGGGTALV RCIPTLEAFL PHLANEDEAI GTRIILKALT 451 APLKQIASKA GKEGAIICQQ VLARSAHEGY DALRDAYTDH IDAGILDPTK 501 VTRSALESAR SIAGLLLTTE ALIADIPEEK SSSAPAMPSA GMDY

$60 \mathrm{kDa}$ Cysteine-Rich OMP/ OmcB/ OMP2 [c. pneumoniae]

1 MSKLIRRVVT VLILTSMASC FASGGIEAMV AESLITKIVA SAETKPAPVP 51 MTAKKVRLVR FNKQPVEQKS RGAFCDKEFY PCEEGRCQPV EAOQESCYGR 101 LYSVKVNDDC NVICQSVPE YATVGSPYPI EILAIGKKDC VDWITQQLP 151 CEAEFVSSDP ETTPTSDGKL VWKIDRLGAG DKCKITVUVK PLKEGCCFTA 201 ATVCACPELR SYTKCGQPAI CIRQEGPDCA CLRCPVCYRI EVWTTGSAIA 251 RNTVDNPVP DGYSHASGQR VLSFNLGDNR PGDKKVFTVE FCPQRRGQIT 301 NVATVTYCGG HKCSANVTTV VNEPCVONNI SGADUSYVCK PVEYSISVSN 351 PGDLVLHDVV IODTLPSGVT VLEAPGGEIC CNKVVURIKE MCPGETLOFK 401 LWNAQVPGR FTNQVAVTSE SNCGTCTSC A ETTTHWKGLA ATHMCVLDTN 451 DPICVGENTV YRICVTNRGS AEDTWSLIL KFSKELQPIA SSGPTKGTIS 501 GNTWFDALP KLGSKESVEF SVTLKGIAPG DARGEAILSS DTLTSPVSDT 551 ENTHVY

truncated foun of outer menbrane protein 2/ 0mcB/ aP2 [C. pneumoniae]

1 IGKKDCVDV ITQQLPCEAE FVSSDPETTP TSDGKLVWKI DRLGAGDKCK 51 ITVUVKPLKE GCCFTAATVC ACFELRSYTK CGQPAICIKQ EGPDCACLRC 101 PVCYKIEVVN TGSAIARNVT VDNPVPDGYS HASGQRVLSF NLGDMRPGDK 151 KVFTVEFCPQ RRGQITNVAT VTYCGGHKCS ANVTTVVNEP CVQNNISGMD 201 WSYUCKPVEY SISVSNPGDL VLFDVIODT LPSGVTVLEA PGGEICCNKV 251 VURIKE KCPG ETLQFKLVVK AQVPGRFTNQ VAVTSESNCG TCTSCAETTT 301 HWKGLAATHM CVLDTNDPIC VGENTVYRIC VTNRGSAEDT WNSLILKFSK 351 ELQPIASSGP TKGTISGNTV VFDALPKLGS KESVEFSVTL KGIAP

Figure 6. Interaction of MIG/CXCL9 and C. pneumoniae EBs. Far-Western blot analysis for identification of the chlamydial ligands responsible for MIG/CXCL9 binding. Concentrated C. pneumoniae and mock control preparations were separated by SDS-PAGE. After blotting, the membrane was probed with recombinant mouse MIG/CXCL9 and incubated with HRP-conjugated anti-MIG IgG (lane 1: molecular weight marker, lane 2: mock preparation, lane 3: Chlamydia EBs treated with MIG/CXCL9 and HRP-conjugated anti-MIG/CXCL9, and lane 4: Chlamydia EBs treated with HRP-conjugated anti-MIG/CXCL9 only (A). Identified MIG/CXCL9-binding proteins of $C$. pneumoniae. Peptide fragments that match the defined protein sequences are underlined (B). 
To show that the MIG/CXCL9 is able to bind to the native EBs, a FACS analysis was carried out. Figure 7B reveals that the Chlamydia EBs interact with MIG/CXCL9 as EBs incubated with MIG/CXCL9 were readily detected after staining with PE-conjugated anti-MIG/CXCL9 IgG. Chlamydia EBs untreated with MIG/CXCL9 were not stained with PE-conjugated antiMIG/CXCL9 IgG (Figure 7C).

$\mathbf{A}$

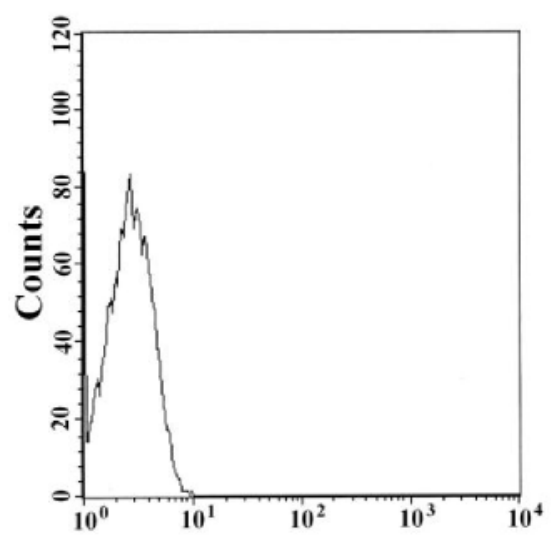

B

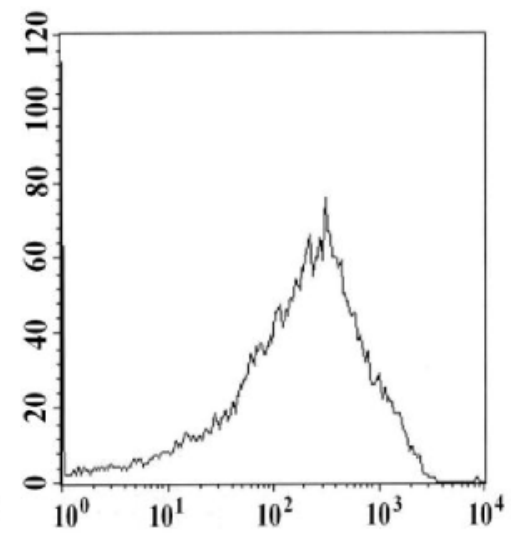

C

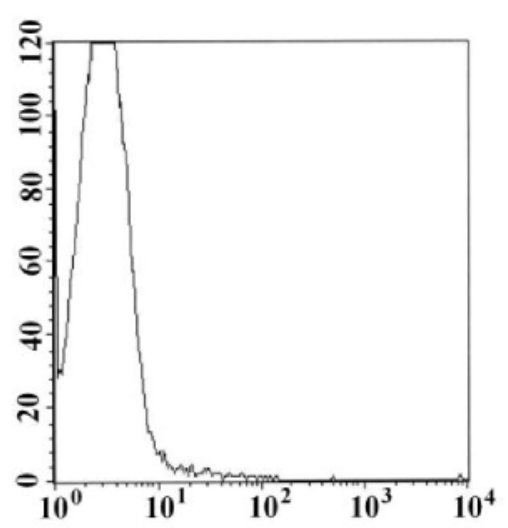

Intensity of Fluorescence

Figure 7. FACS analysis for the detection of MIG/CXCL9 binding to wholeC pneumoniae EBs. Untreated and unstained Chlamydia EBs (A). MIG/CXCL9 protein-treated and PE-labelled anti-MIG/CXCL9-stained $C$. pneumoniae EBs (B). Chlamydia EBs stained with PE-labelled anti-MIG/CXCL9 antibody (C). 


\subsection{C. trachomatis experiments}

\subsubsection{Anti-chlamydial effect of plant peptides.}

To determine whether they possess anti-chlamydial activity, 11 NCR peptides (NCR030, NC0R44, NCR055, NCR095, NCR137, NCR168, NCR169, NCR183, NCR192 NCR247 and NCR280) were co-incubated individually with C. trachomatis EBs at $10 \mathrm{~g} / \mathrm{ml}$ for $2 \mathrm{~h}$ at $37{ }^{\circ} \mathrm{C}$. Coun ting of the number of viable $C$. trachomatis inclusions demonstrated that 7 of the 11 peptides (NCR044, NCR055, NCR095, NCR183, NCR192, NCR247 and NCR280) were effective killers of $C$. trachomatis in vitro, while NCR030 and NCR168 displayed weaker activity, and NCR137 and NCR169 did not exert an anti-chlamydial effect (Figure 8A). C. trachomatis inclusions were then treated for $2 \mathrm{~h}$ with concentrations of the peptides ranging from $1.25 \square \mathrm{g} / \mathrm{ml}$ to $10 \square \mathrm{g} / \mathrm{ml}$ (Figure 8B). NCR044, NCR055 and NCR183 

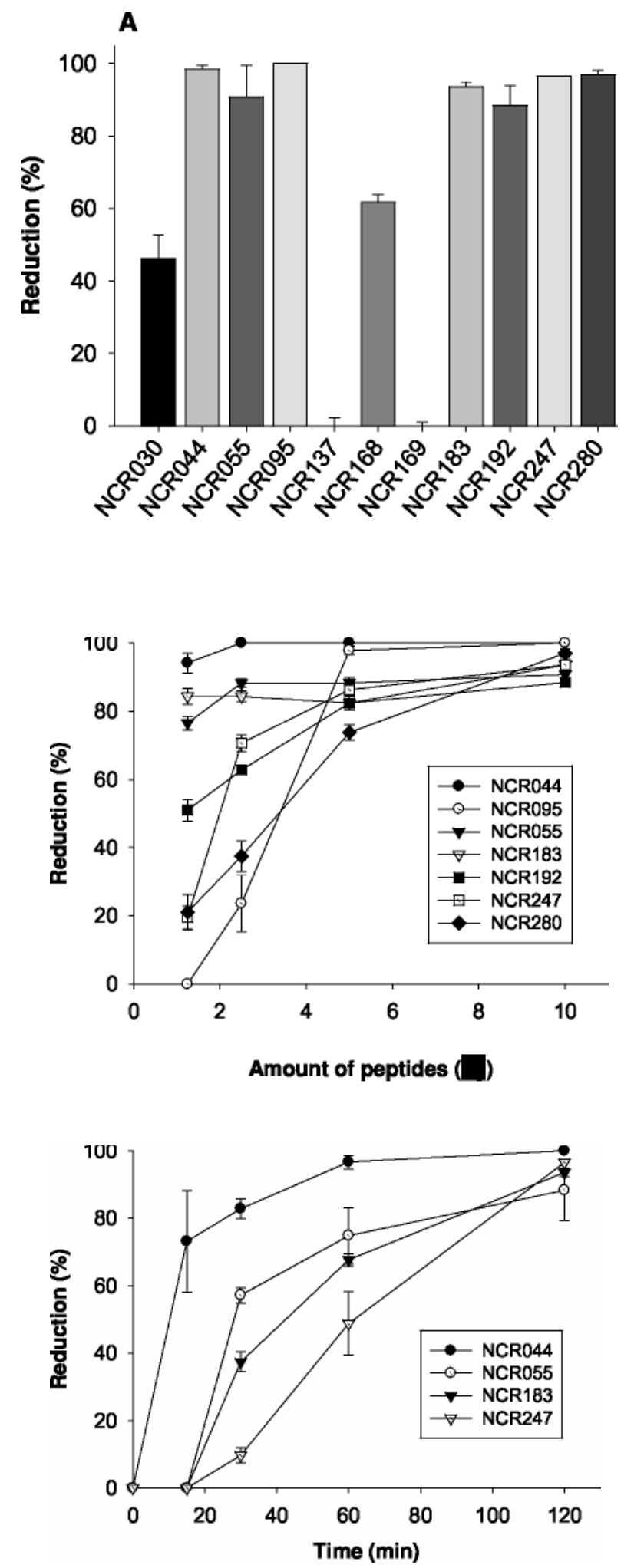

Figure 8. Concentration and time dependences of the anti-chlamydial effects of NCR peptides.C. trachomatis at $4 \times 10^{4} \mathrm{IFU} / \mathrm{ml}$ was incubated with $10 \mathrm{~g} / \mathrm{ml}$ of synthetic NCR peptide for $2 \mathrm{~h}$ at $37{ }^{\circ} \mathrm{C}$ (A).C. trachomatis EBs 
were incubated with different quantities of synthetic NCR peptides for $2 \mathrm{~h}$ at $37{ }^{\circ} \mathrm{C}$ (B) C. trachomatis was coincubated individually with different NCR peptides $(5 \mathrm{~g} / \mathrm{ml})$ for $0,15,30,60$ or $120 \mathrm{~min}(\mathrm{C})$. The infectivity of the NCR peptide-treated $C$. trachomatis was determined by inoculating the mixture onto confluent HeLa cells on cover glasses. After a 24-h incubation, the fixed cells were stained with anti-chlamydia LPS antibody and the number of inclusions was counted under a UV microscope. All the data are representative of three separat experiments.

\subsubsection{Identification of the chlamydial ligand responsible for NCR247 binding}

Further investigations were carried out with NCR247, which displayed antichlamydial activity in the previous tests.

To identify the chlamydial ligand responsible for NCR peptide binding, concentrated $C$. trachomatis EB preparations and mock control preparations were separated by SDS-PAGE. After blotting, the membranes were probed with synthetic NCR247 peptide and incubated with anti-NCR247 IgG, and then with HRP-labelled anti-rabbit antibody. The control lane with Chlamydia EBs was stained with anti-NCR247 IgG and HRP-labelled anti-rabbit antibody without incubation with synthetic NCR247 peptide. The synthetic NCR247 peptide was bound to a $60-\mathrm{kDa}$ protein band in the Chlamydia lysate (Figure 9A, lane 4). The synthetic NCR247 did not react with the mock lysate (lane 2), and the Chlamydia EB lysate did not react with the HRP-conjugated anti-rabbit antibody (lane 3). The gel slice containing the corresponding polypeptide of the concentrated $C$. trachomatis EBs associated with the synthetic NCR247 peptide was cut out from the gel and analyzed by LC-MSMS. A $60 \mathrm{kDa}$ putative GroEL protein of Chlamydia was indicated by LC-MSMS and confirmed by post source decay analysis (Figure 9B). 


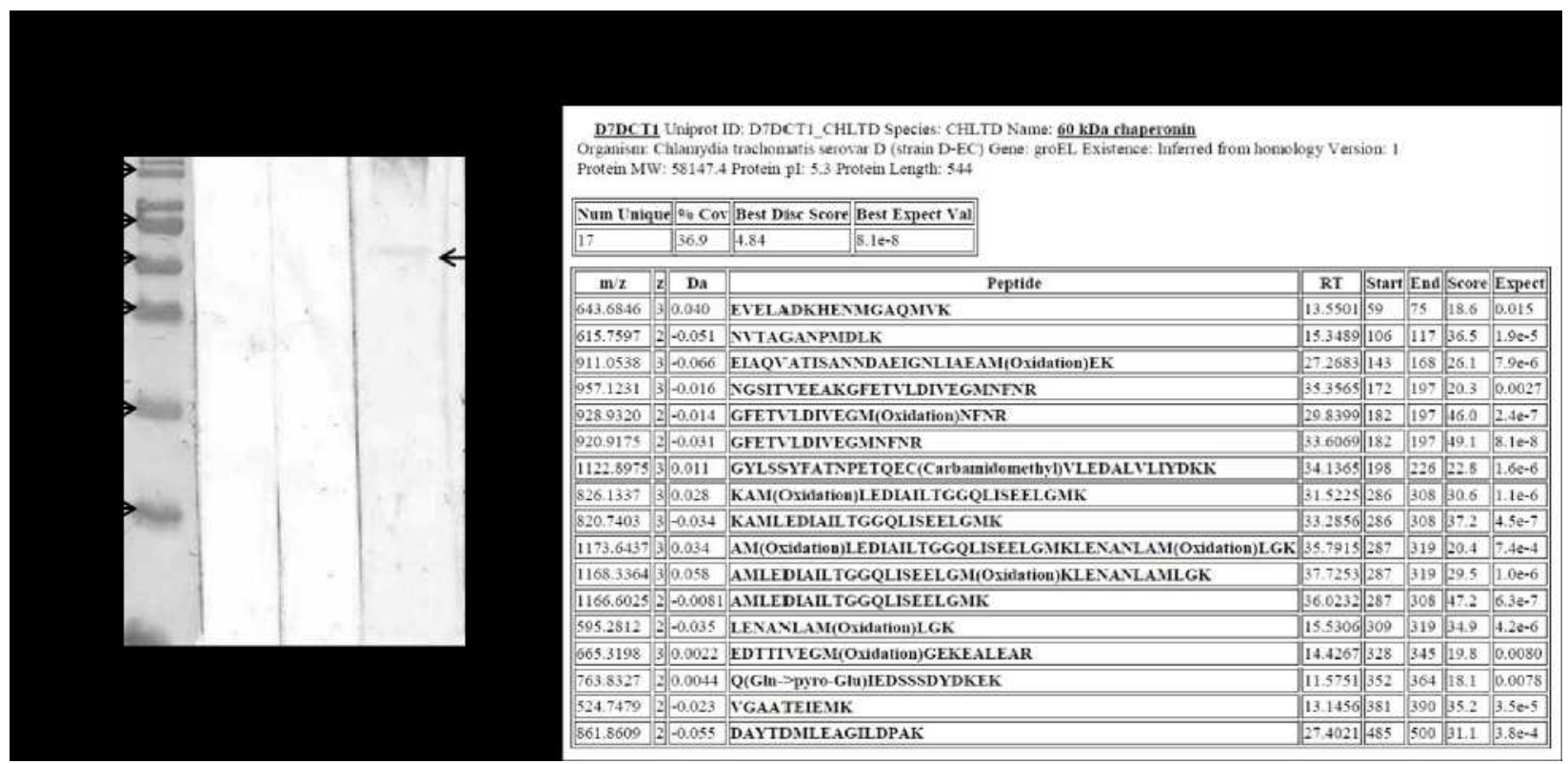

Figure 9. Interaction of NCR247 peptide and C. trachomatis EBs. Far-Western blot analysis of the chlamydial ligands responsible for NCR247 peptide binding. (A) Concentrated C. trachomatis and mock control preparations were separated by SDS-PAGE. After blotting, the membrane (lane 2,4) was probed with synthetic NCR247 peptide and incubated with anti-NCR247 IgG and HRP-labelled anti-rabbit antibody. (lane 1-molecular weight marker, lane 2 - mock preparation, lane 4 - Chlamydia EBs lysate). A control lane (lane 3) with separated C. trachomatis EBs was also incubated with anti-NCR247 and HRP-conjugated anti-rabbit antibody without prior treatment with the NCR247 peptide. Identification of the C. trachomatis proteins by LCMSMS (B). Peptide fragments that match the defined protein sequences are to be found in the Table.

\subsubsection{FACS analysis for the detection of NCR247 binding to the wholeC. trachomatis EBs}

To show that NCR247 is able to bind not only to the degraded Chlamydia particles but to the native, viable Chlamydia EBs, a FACS analysis was carried out. Figure 10 reveals that Chlamydia EBs interacted with FITC-conjugated NCR247 peptide. Untreated or FITC-labelled NCR035 peptide-treated (this peptide showed no anti-chlamydial effect earlier) Chlamydia EBs did not demonstrate increased fluorescence. 

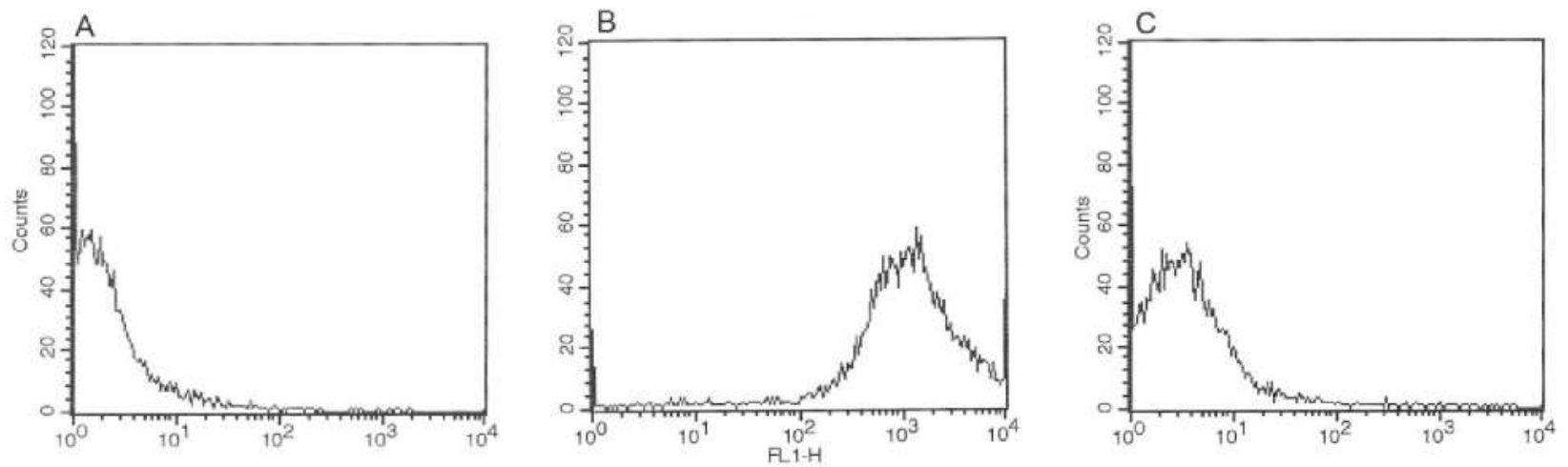

Figure 10. FACS analysis of NCR247 peptide binding to whole C. trachomatis EBs. Untreated and unstained Chlamydia EBs (A). FITC-labelled NCR247 peptide treated C. trachomatis EBs (B). Chlamydia EBs treated with FITC-labelled NCR035 peptide (C). 


\section{Discussion}

Innate or natural immunity is the principal pathway for the effective elimination of most bacterial pathogens from the lung (Nelson et al., 1995). Antimicrobial peptides such as defensins are natural peptide antibiotics. When the host is challenged by microbes, these peptides act as the first line of innate defence before the activation of adaptive immunity. The defensins and certain chemokines, e.g. MIG/CXCL9, have similar characteristics, including size, disulphide bonding, IFN inducibility, a cationic charge at neutral $\mathrm{pH}$, and the antimicrobial activity (Cole et al., 2001). Innate immune responses are enhanced in the presence of type 1 cytokines, including IL-12 and IFN- (Moore et al., 2002; Rubins and Pomeroy, 1997). Type 1 cytokine responses are indispensable for the effective killing of intracellular pathogens (Deng et al., 2001). Our aims were to reveal whether C. pneumoniae can induce the production of CXCL chemokines in vitro and in in vivo mouse model, and to detect the possible anti-chlamydial activity of CXCL chemokines in vitro. Our study revealed that $C$. pneumoniae can induce MIG/CXCL9 expression both in vitro and in vivo, and that MIG/CXCL9 has anti-chlamydial activity. Moreover, the potential chlamydial ligand of MIG/CXCL9 was suggested.

The time course of the effect of IFN-, which is the main inducer of MIG/CXCL9 production following C. pneumoniae infection, was described earlier (Burian et al., 2003; Geng et al., 2000). The in vivo kinetics of MIG/CXCL9 mRNA expression was similar to that of the recovery of viable Chlamydiae from the lungs after infection: the expression of the MIG/CXCL9 mRNA and the number of culturable Chlamydia inclusions were highest on day 7, while at 4 weeks after infection the MIG/CXCL9 mRNA expression remained higher in the infected mice than in the controls, whereas the number of culturable $C$. pneumoniae inclusions had decreased to an undetectable level. The expression of IP-10/CXCL10 and I - TAC/CXCL1 1 mRNA, in contrast with MIG/CXCL9 expression, peaked on day 4. The finding that IP10/CXC10 expression was highest on day 4 coincided with the result published by Maxion et al., that the level of IP-10/CXCL10 was highest on day 4 in the upper genital tract of mice after C. trachomatis infection (Maxion et al., 2002). The highest concentration of MIG/CXCL9 at a protein level was likewise observed on day 7. The Th1 cytokine IFN- plays important roles in combating acute Chlamydia infection and in the establishment of persistence (Rottenberg, 2002). IFN- may also play a regulatory role in 
chlamydial defence, via its ability to alter the Th1/Th2 balance. Accordingly, IFN- gene knockout mice exhibited Th2-cytokine-dependent immunopathology together with disseminated chlamydial infection (Wang et al., 1999). IFN- may modify the outcome of infection by enhancing the expression of chemokines and adhesion molecules. IFN-administered therapeutically to patients with chronic granulomatous disease improved the ability of phagocytes to clear bacterial infections (Billiau and Matthys, 2009). Although there is still some controversy, it is quite plausible that the increase in antimicrobial activity results from oxygen-independent bactericidal mechanisms, including the IFN--inducible ELR-negative CXC chemokines. If, as might be expected, even higher concentrations prevail in the microenvironment of chemokine-secreting cells, antimicrobial effects could occur through the individual or combined activities of one or more of these chemokines. It is important that MIG/CXCL9 is not compartmentalized in the lungs, since we detected it in the circulation between days 7 and 14 after C. pneumoniae infection, which suggests an important role of MIG/CXCL9 in the resolution of the infection. An elevated MIG/CXCL9 content has also been measured in the human plasma duringBurkholderia pseudomallei infection (Lauw et al., 2000).

We found that in vitro infection with $C$. pneumoniae induced MIG/CXCL9 production from day 3 in J774A cells, and from day 2 in infected mouse fibroblasts. It is interesting that mouse fibroblasts produced significantly more MIG/CXCL9 than did the macrophage cell line J774A (Figure 4A,B). It has been reported that cellular processes of non-immune cells (epithelial and endothelial cells and fibroblasts) triggered by chlamydial infection provoke the influx of inflammatory neutrophils, T cells, B cells and macrophages stimulated by the milieu of proinflammatory cytokines and chemokines (Stephens, 2003). It was surprising that co-treatment of the mouse fibroblasts with a dose ofC. pneumoniae, which was unable to induce MIG/CXCL9 production on day 1 , and with $10 \mathrm{U}$ of IFN- resulted in a 51.8-fold increase in MIG/CXCL9 release as compared with treatment with $10 \mathrm{U}$ of IFN- alone. Our observation that heatinactivated $C$. pneumoniae together with IFN- induced a 75-fold increase in MIG/CXCL9 secretion relative to IFN- treatment alone suggests the heat-stable LPS as the putative chlamydial component responsible for the stimulation of MIG/CXCL9 production. Besides the respiratory $C$. pneumoniae strain CWL029, the cardiovascular strain CV6 was shown to stimulate the production of MIG/CXCL9. Similarly to our results, Högdahlet al. 
found that $C$. pneumoniae $\mathrm{T} 45$, a respiratory strain isolate, induces the production of chemokines such as IL-8, MCP-1, RANTES, IP-10 and MIG/CXCL9 in human coronary artery endothelial cells after $48 \mathrm{~h}$ (Högdahl et al., 2008).

Our experiments demonstrated that recombinant MIG/CXCL9 can inhibitC. pneumoniae in a dose-dependent manner. A previous work has revealed that MIG/CXCL9 and IP-10/CXCL10 bear antibacterial effect against Escherichia coli and Listeria monocyto genes (Cole et al., 2001). It was recently reported that CXCL9, CXCL10 and CXCL1 1 kill Streptococcus pyo genes, and that, in particular, CXCL9 was produced in a bactericidal concentration by inflamed pharyngeal cells both in vivo and in vitro (Egesten et al., 2009). The role of MIG/CXCL9 during bacterial infection has not been fully elucidated. In contrast with the examples mentioned above, in the case of Fine goldia magna MIG/CXCL9 displays no antibacterial activity. Moreover, the SufA of F. magna cleaves MIG/CXCL9 (Karls son et al., 2009, Karlsson et al., 2007). In our in vivo experiments, MIG/CXCL9 concentration in the whole lung suspension in the ELISA test was lower than the lowest bactericidal concentration in the in vitro test, but the local chemokine concentration should be higher in the affected area of the lung. Indeed, as MIG/CXCL9 has affinity for heparin, the local concentration might be even higher. Thus, interactions with glucosaminoglycans (GAGs) can retain MIG/CXCL9 at epithelial surfaces and further increase the local concentration. It has been suggested that the binding of chemokines to GAGs may furnish a chemotactic gradient to recruit leukocytes during inflammation (Egesten et al., 2007; Handel et al., 2005). Since MIG/CXCL9 was antichlamydial only when it was co-incubated (for at least $15 \mathrm{~min}$ ) with the EBs, it is likely that the expressed MIG/CXCL9 does not exert an effect on already infected epithelial cells, but rather prevents the spread of infectious EBs extracellularly.

By means of mass spectrometry, we identified three kinds of chlamydial proteins. We found that MIG/CXCL9 binds to OmcB, which has been identified as a major component of the chlamydial outer membrane complex, and is conserved among all chlamydial species (Wagels et al., 1994). OmcB was initially thought to be an intimate part of the outer membrane fraction of the chlamydial outer membrane complex. However, according to others, OmcB was resistant to trypsin digestion, which supported its lack of surface exposure (Everett and Hatch, 1995). Nonetheless, Moelleken and Hegemann established a yeast adhesion system in which the binding of live OmcB-presenting yeast cells to human cells could be studied. They 
showed that the $\mathrm{OmcB}$ protein from $C$. pneumoniae mediates adhesion to HEp-2 cells (Moelleken and Hegemann, 2008). Moreover, OmcB induces a strong antibody response suggesting that it is readily accessible to the humoral immune response, which is indicative o a surface localization (Cunningham and Wards, 2003; Portig et al., 2003). Since OmcB protein is present on the surface, MIG/CXCL9 can bind to it. This is supported by our finding that the truncated form of $\mathrm{OmcB}$ (the $30 \mathrm{kDa}$ protein) was the other protein identified by LCMSMS. During the denaturation process for the binding assay, this intermediate form of OmcB could be released from the EBs. Our results are also in accordance with MIG/CXCL9 having affinity for heparin (Handel et al., 2005). It is interesting that heparin-like (GAG) structures on the mammalian cell surface play an important role in the interactions with many bacterial pathogens and are recognized by chlamydial OmcB (Moelleken and Hegemann, 2008). Moreover, the M1 protein, the major surface protein of $S$. pyo genes, which is necessary for the adhesion of bacteria to epithelial cells via GAGs, induces an enhanced production of MIG/CXCL9 (Eliasson et al., 2007 and 2010). The third protein identified by mass spectrometry is the putative GroEL protein of C. pneumoniae. Wuppermann et al. recently described the localization of GroEL1 on the surface of the EBs, and the ability of GroEL1 to bind to MIG/CXCL9 therefore cannot be excluded (Wuppermann et al., 2008). Since our results showed that MIG/CXCL9 binds not only to the full OmcB protein, but also to its truncated form, and the role of OmcB protein in the initiation of infection is well documented, we concluded that binding to this protein is of major significance.

Our FACS experiment confirmed that MIG/CXCL9 binds not only to the denatured proteins of the EBs, but also to the viable native form, supporting the antibacterial capability of this chemokine.

Overall, these results indicate that $C$. pneumoniae has the capability to induce the production of MIG/CXCL9, IP-10/CXCL10 and I-TAC/CXCL1 1 in vivo, and the production of MIG/CXCL9 in vitro. MIG/CXCL9 production did not require the presence of viable Chlamydiae. Our work was the first report about the anti-chlamydial activity of recombinant MIG/CXCL9, and about the role of the $60 \mathrm{kDa}$ proteins in the binding of MIG/CXCL9 to the chlamydial cells. Thus, MIG/CXCL9 released by sentinel and non-immune cells could directly target and inactivate microbial pathogens, while also serving as a signal for the recruitment of leukocytes to infected tissues. 
Because of the severity of $C$. trachomatis-caused infections and their consequences we were concerned about searching for new anti-chlamydial compounds. As mentioned above, $C$. trachomatis is the leading cause of sexually transmitted bacterial diseases in both developed and developing countries, with more than 90 million new cases of genital infections occurring annually. The development of effective new antimicrobial compounds is indispensable to avoid the late severe sequelae of the infections, such as ectopic pregnancy and infertility (WHO, 1996). AMPs appear to be potentially promising candidates for this purpose. It was demonstrated that the synthetic tomato defensin peptide exhibits potent antibacterial activity against Gram-positive bacteria, such as Staphylococcus. aureus A170, Streptococcus. epidermidis, and Listeria. monocyto genes, and Gram-negative bacteria, including Salmonella enterica serovar Paratyphi, E. coli, and Helicobacter pylori (Rigano et al., 2012). In addition, the synthetic peptide shows minimal $(<5 \%)$ hemolytic activity and absence of cytotoxic effects against THP-1 cells. Although their antimicrobial activity against bacteria, fungi and protozoa has been extensively studied (Rigano et al., 2012), their anti-chlamydial action has not yet been tested. In the present study, therefore, we investigated the in vitro activity of 11 NCR peptides against $C$. trachomatis. Seven of these peptides exerted significant antichlamydial activity at a $10 \mathrm{~g} / \mathrm{ml}$ concentration. A number of synthetic NCR peptides from Medicago truncatula have been reported to be potent killers of various Gram-negative (Escherichia coli, Salmonella Typhimurium, Agrobacterium tumefaciens, Pseudomonas aeruginosa and Xanthomonas campestris) and Gram-positive (Bacillus megaterium, Bacillus cereus, Clavibacter michiganensis, Staphylococcus aureus and Listeria monocyto genes) bacteria, including human/animal and plant pathogens (Tiricz et al., 2013). Furthermore, AMPs were effective against Staphylococcus epidermidis in in vivo mouse model, and they also displayed antiinflammatory activity (Capparelli et al., 2012).

Our LC-MSMS experiment identified the GroEL protein of $C$. trachomatis as the chlamydial ligand of the NCR247 peptide. The GroEL protein is one of the few proteins that have so far been confirmed as relevant in chlamydial pathogenesis; it is also referred to as heat shock protein 60 (Hsp60) (Ward, 1999). This protein belongs to group I chaperones produced by almost all prokaryotic and eukaryotic cells, which assist as intracellular proteins, in the correct folding of nascent or denatured proteins under both normal and stress conditions (Zügel and Kaufmann, 1999). Several reports have indicated that molecular chaperones 
produced by pathogenic bacteria, can function as intracellular, cell surface, or extracellula signals in the course of infection processes (Henderson et al., 2006). The immune responses to chlamydial GroEL correlate significantly with disease sequelae in humans, and 80 to $90 \%$ of patients infected with $C$. trachomatis have antibodies directed against GroEL (Horner et al., 1997). The high degree of antigenicity of GroEL in patients implies that the protein $i$ easily accessible to the immune system, perhaps becauseit is localized on the surface of the chlamydial particles. Early studies on isolated outer membrane complexes from C. trachomatis and $C$. psittaci EBs had indeed pointed to the possibility that GroEL might be associated with chlamydial membranes (Bavoil et al., 1990). Taken together, GroEL is accessible for the binding of NCR247 peptide.

Our study indicates that certain NCR peptides possess substantial in vitro activity against C. trachomatis D. Studies of chlamydial infection in animal models are clearly needed to establish whether they have parallel in vivo results and whether these peptides can be useful lead compounds for the development of anti-chlamydial drugs. 


\section{The following of our results are considered novel}

1. We found that MIG/CXCL9 showed dose-dependent anti-chlamydial activity in in vitro $C$. pneumoniae infection.

2. During our experiments it was revealed that the $60 \mathrm{kDa}$ chlamydial proteins were responsible for the binding of MIG/CXCL9.

3. Seven of the NCR peptides examined showed dose dependent anti-chlamydial effect in in vitro C. trachomatis infection.

4. We found the chlamydial GroEL protein to be responsible for the binding of NCR247 peptide. 


\section{Summary}

Chlamydophila pneumoniae and Chlamydia trachomatis are obligate intracellular parasites that belong to the family of Chlamydiaceae. These bacteria have the ability to cause prolonged and often subclinical infections.

C. pneumoniae causes approximately $10 \%$ of community-acquired pneumonia cases among adults. Although most of the acute infections with $C$. pneumoniae are probably asymptomatic, they may be frequently associated clinically with pneumonia and bronchitis; moreover, $C$. pneumoniae infections have also been linked to the development of heart diseases and atherosclerosis.

C. trachomatis has three human serotypes. Serovars D-K cause sexually transmitted diseases, which are of great public health significance. Cervicitis and urethritis commonly occur in women and about $40 \%$ of the untreated cases progress to pelvic inflammatory disease (PID). Infertility is the result in $20 \%$ of the PID cases, while $18 \%$ of the women with this disease experience chronic pelvic pain, and 9\% may suffer an ectopic pregnancy. At the individual level, the diseases caused by $C$. trachomatis can generally be treated effectively with antibiotics, but at the population level, public health control of the infections is rather problematic. Vaccination, which is currently unavailable, would be the best way to reduce the prevalence of $C$. trachomatis infections, as it would be much cheaper and more effective in controlling chlamydial diseases. $C$. trachomatis has been reported to adopt an intracellular form that is metabolically less active and thus less sensitive to antibiotics. The development of new antimicrobial agents is required for the effective treatment of persistent chlamydial infections.

CXC chemokines that lack the ELR (glutamic acid-leucine-arginine) motif, including the monokine induced by IFN- (MIG/CXCL9), the IFN-induced protein of $10 \mathrm{kDa}$ (IP10/CXCL10), and the IFN-inducible T-cell -chemoattractant (ITAC/CXCL1 1), have been shown to mediate the generation of type 1 immune responses and to possess defensin-like bactericidal effects. Our study revealed that the infection of mice with $C$. pneumoniae via the intranasal route resulted in the local expression of MIG/CXCL9, IP-10/CXCL10, and I TAC/CXCL1 1. MIG/CXCL9 was also detected at a protein level from day 1, with the highest concentration in the supernatants of the infected lungs on day 7. The expression of IFNdisplayed similar kinetics. C. pneumoniae and its inactivated form also induced the 
production of MIG/CXCL9 in mouse fibroblasts and in the murine macrophage cell line J774A in vitro. Co-treatment of the tissue cultures with $C$. pneumoniae and different quantities of IFNresulted in strong increases in MIG/CXCL9 production. Recombinan MIG/CXCL9 exerted dose-dependent antibacterial activity against $C$. pneumoniae. In our in vivo experiments, MIG/CXCL9 concentration in the whole lung suspension in the ELISA test was lower than the lowest bactericidal concentration in the in vitro test, but the local chemokine concentration should be higher in the affected area of the lung. Since MIG/CXCL9 seemed to bear antichlamydial effect only when it was co-incubated (for at least 15 min) with the EBs, it is likely that the expressed MIG/CXCL9 does not exert an effect on already infected epithelial cells, but rather prevents the spread of infectious EBs extracellularly. Chlamydial proteins at a molecular weight of $60 \mathrm{kDa}$ were identified by Far-Western blot assay and liquid chromatography-tandem mass spectrometry as binding molecules of MIG/CXCL9. The results of these experiments suggest that MIG/CXCL9 might play an important role in the innate and acquired defence mechanisms against $C$. pneumoniae. Antimicrobial peptides (AMPs) are natural antibiotics produced by nearly all organisms, from bacteria to plants and animals. Most plant AMPs are cysteine cluster proteins. This group includes major plant immunity effectors such as defensins, and also symbiotic peptides, including the nodule-specific cysteine rich (NCR) peptides. Some cationic NCRs have been shown to possess genuine antimicrobial activities in vitro, killing various Gram-negative and Gram-positive bacteria highly efficiently. In our present study, 7 of the 11 NCR peptides examined displayed dose- and time-dependent anti-chlamydial activity in vitro. NCR247 was demonstrated to bind to the $60-\mathrm{kDa}$ putative GroEL protein of $C$. trachomatis. 


\section{9. Összefoglalás}

A Chlamydophila pneumoniae és Chlamydia trachomatis a Chlamydiaceae családba tartoz $^{\mathrm{y}}$ obligát intracellularis paraziták. Ezen baktériumok gyakran elhúz $\mathrm{z}^{\mathrm{y}} \mathrm{d}^{\mathrm{y}}$, tünetmentes fertőzéseket hoznak létre.

A C. pneumoniae felelôs a felnốttek közösségben szerzett tüdôgyulladásának kb. 10\%-áért. Habár az akut fertôzések nagy része val ${ }^{\mathrm{y}}$ színúleg tünetmentes, a betegség manifesztál ${ }^{\mathrm{y}}$ dhat pneumonia vagy bronchitis képében; sốt, a C. pneumoniae által okozott infekci ${ }^{\mathrm{y}} \mathrm{knak}$ szerepük lehet egyes szívbetegségek és az atherosclerosis kialakulásában is.

A C. trachomatis-nak három human szerotípusa ismert. A D-K szerovariánsok szexuális úton átvihetô fertôzéseket okoznak, amelyeknek népegészségügyi jelentősége kiemelkedô. Nôknél a fertôzés gyakran cervicitist és urethritis t okoz, amelyek kezeletlen esetben 40\%-ban progrediálnak kismedencei gyulladássá (pelvic inflammatory dis ease, PID). A PID esetek 9\%ában ectopiás terhesség, 18\%-ában $\mathrm{kr}^{\mathrm{y}}$ nikus kismedencei fájdalom, 20\%-ban terméketlenség a következmény. Habár egyéni szinten jyl kezelhetôek a C. trachomatis infekci ${ }^{\mathrm{y}} \mathrm{k}$, populáci ${ }^{\mathrm{y}} \mathrm{s}$ szinten rendkívüli nehézséggel jár a fertőzések kordában tartása. A jelenleg még nem elérhető vakcináci ${ }^{\mathrm{y}}$ lenne a leghatékonyabb $\mathrm{m}^{\mathrm{y}} \mathrm{dszer}$ a $C$. trachomatis által okozott betegségek prevalenciájának csökkentésére. Mivel a C. trachomatis képes egy metabolikusan kevéssé aktív és így az antibiotikumokra fokozottan rezisztens formában túlélni a sejten belül, új antimikrobiális szerek kifejlesztése kiemelkedően fontos.

Az ELR (glutaminsav-leucin-arginin) motívumot nem tartalmaz ${ }^{\mathrm{y}}$ CXC chemokinek, így a MIG/CXCL9 (monokine induced by IFN- az IP-10/CXCL10 (IFN-induced protein of $10 \mathrm{kDa}$ ), és az ITAC/CXCL1 1 (IFN-inducible T-cell -chemoattractant) az 1-es típusú immunválasz kiváltásában játszanak szerepet, valamint defenzin-szerú baktericid hatással bírnak. Kísérleteink során egereket fertôztünk intranasalisan $C$. pneumoniae-val, amely hatására a MIG/CXCL9, IP-10/CXCL10, és I-TAC/CXCL11 lokálisan expresszál ${ }^{\mathbf{y}}$ dott az egerek tüdejében. A fertôzés utáni elsố napt ${ }^{\mathrm{y}} 1$ a MIG/CXCL9 protein szinten is detektálhat ${ }^{\mathrm{y}}$ volt, legmagasabb koncentráci ${ }^{\mathrm{y}}$ ban a fertôzést követô 7. napon. Az IFN- expresszi ${ }^{\mathrm{y}} \mathrm{ja} \mathrm{hasonl}^{\mathrm{y}}$ kinetikát mutatott.

C. pneumoniae élő és elölt formája hatására in vitro is megindult a MIG/CXCL9 termelődés az általunk használt egér fibroblast és J774A macrophag sejtvonalban. A sejtkultúrák egyidejú

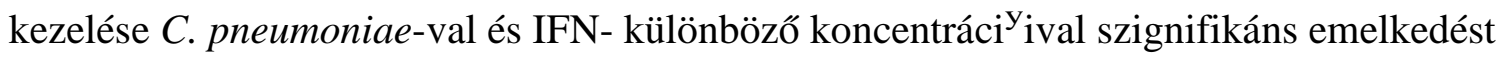


indukált a MIG/CXCL9 termelődésben. Az alkalmazott rekombin áns MIG/CXCL9 d ${ }^{\mathrm{y}}{ }_{\text {zis- }}$ dependens antibakteriális hatással rendelkezett a C. pneumoniae-val szemben. In vivo kísérleteinkben a MIG/CXCL9 kon cen tráci ${ }^{\mathrm{y}} \mathrm{ja}$ alacson yabb volt, min $\mathrm{t}$ azin vitro tesztekben hatásos koncentráci ${ }^{\mathrm{y}}$, de a lokális chemokin szint val${ }^{\mathrm{y}}$ színúleg magasabb az érintett tüdőterületeken. Mivel a MIG/CXCL9 csak akkor mutatott anti-chlamydialis aktivitást, ha legalább 15 percig együtt in kubáltuk a chlamydia elementáris testekkel, valy színúsíthetô, hogy az expresszált MIG/CXCL9 nem a már fertőzött sejteken fejti ki hatását, han em extracellularisan akadályozza a fertőző elementáris testek terjedését.

Far- Wes tern blot és LC-MSMS (folyadékkromatográfia-tömegspektrometria) vizsgálat során 60 kDa molekulatömegû chlamydialis fehérjéket azonosítottunk a MIG/CXCL9 kötô partnereként. Ezen eredmények azt sugallják, hogy a MIG/CXCL9 fontos szerepet játszhat mind a veleszületett, mind pedig a szerzett anti-chlamydialis védekezô mechanizmusokban. Az antimikrobialis peptidek olyan természetes anitibiotikumok, amelyek termelésére rengeteg élő szervezet képes, a baktériumokt ${ }^{\mathrm{y}} 1$ anövényeken át az állatokig. A legtöbb antimikrobialis peptid ciszteinben gazdag fehérje. Ebbe a csoportba tartoznak olyan kiemelkedően fontos növényi immunitást szabályz ${ }^{\mathrm{y}}$ fehérjék, mint a defenzinekvagy a gümô-specifikus ciszteingazdag (Nodule-specific Cysteine-Rich, NCR) peptidek. Néhány kationos NCR ismert antimikrobiális hatással rendelkezik in vitro Gram-negatív és Gram-pozitív baktériumokkal szemben. Kísérleteink során 7 növényi peptid fejtett ki d $\mathrm{d}^{\mathrm{y}} \mathrm{zis}-$, valamint idôfüggó antichlamydialis hatást in vitro. Az NCR 247 peptid kötố partnereként a C. trachomatis $60 \mathrm{kDa}$ molekulatömegú GroEL fehérjéjét azonosítottuk. 


\section{Acknowledgements}

I would like to thank my tutor, Katalin Burián for guiding me through the maze of microbiology, and for always helping me with every question and problem I had.

I owe many thanks to my colleagues, especially toTímea Mosolygó and Valéria Endrész, for their help over the years.

For the excellent technical assistance I should express my gratitude toTilda (Istvánné Lévai) and Gizike (Gizella Paraginé Zsótér).

This thesis is dedicated to my parents, who I owe the most

This work was supported by OTKA National Research Fund Grant PD 100442, and Gran TÁMOP-4.2.2.A- 11-1 -KONV-20 1 2-0035 from the New Széchenyi Plan. 


\section{References}

1. Alunni B, Kevei Z, Redondo-Nieto M, Kondorosi A, Mergaert P, Kondorosi E. Genomic organization and evolutionary insights on GRP and NCR genes, two large nodule-specific gene families in Medicago truncatula. Mol Plant Microbe Interact 20:1138-1 148. (2007)

2. Baggiolini M. Chemokines in pathology and medicine. J Intern.Med. 250, 91-104. (2001)

3. Bai X, Chmura K, Ovrutsky AR, Bowler RP, Scheinman RI, Oberley-Deegan RE, Liu H, Shang S, Ordway D, Chan ED. Mycobacterium tuberculosis increases IP-10 and MIG protein despite inhibition of IP-10 and MIG transcription. Tuberculosis (Edinb). 91(1):26-35. (2011)

4. Balogh EP, Faludi I , Vir ${ }^{\mathrm{y}} \mathrm{k}$ DP, Endrész V, Burián K. Chlamydophila pneumoniae induces production of the defensin-like MIG/CXCL9, which has in vitro antichlamydial activity. Int J Med Microbiol. 301(3):252-9. (2011)

5. Balogh EP, Mosolyg ${ }^{\mathrm{y}} \mathrm{T}$, Tiricz H, Szab ${ }^{\mathrm{y}}$ ÁM, Karai A, Kerekes F, Vir ${ }^{\mathrm{y}} \mathrm{k}$ DP, Kondorosi É, Burián K. Anti-chlamydial effect of plant peptides. Acta Microbiologica et Immunologica Hungarica. (ahead of print) (2014)

6. Bavoil P, Stephens RS, Falkow S.: A soluble 60 kiloDalton antigen of Chlamydia. Mol Microbiol. 4(3):461-9. (1990)

7. Belland RJ, Ouellette SP, Gieffers J, Byrne GI. Chlamydia pneumoniae and atherosclerosis. Cell Microbiol. 6:117-127. (2004)

8. Billiau A, Matthys P. Interferon-gamma: a historical perspective. Cytokine Growth 
Factor Rev. 20, 97-113. (2009)

9. Blasi F, Tarsia P, Aliberti S. Chlamydophila pneumoniae. Clin Microbiol Infect. 15:2935. (2009)

10. Brogden NK, Brogden KA. Will new generations of modified antimicrobial peptides improve their potential as pharmaceuticals? Int J Antimicrob Agents 38:217-225 (2011)

11. Burian K, Kis Z, Virok D, Endresz V, Prohaszka Z, Duba J, Berencsi K, Boda K, Horvath L, Romics L, Fust G, Gonczo, E. Independent and joint effects of antibodies to human heat-shock protein 60 and Chlamydia pneumoniae infection in the development of coronary atherosclerosis. Circulation 103:1503-1508. (2001)

12. Burián K, Hegyesi H, Buzás E, Endrész V, Kis Z, Falus A, Gönczöl E. Chlamydophila (Chlamydia) pneumoniae induces histidine decarboxylase production in the mouse lung. Immunol Lett. 89:229-236. (2003)

13. Burian K, Endresz V, Deak J, Kormanyos Z, Pal A, Nelson D, Virok D. Transcriptome analysis indicates an enhanced activation of adaptive and innate immunity by chlamydia-infected murine epithelial cells treated with interferon $\mathrm{\square}$. J Infect Dis. 202(9):1405-14. (2010)

14. Burian K, Berencsi K, Endresz V, Gyulai Z, Valyi-Nagy T, Valyi-Nagy I, Bakay M, Geng Y, Virok D, Kari L, Hajnal-Papp R, Trinchieri G, Gonczol E. Chlamydia pneumoniae exacerbates aortic inflammatory foci caused by murine cytomegalovirus infection in normocholesterolemic mice. Clin Diagn Lab Immunol. 8(6): 1263-6. (2001)

15. Caldwell HD, Kromhout J, Schachter J. Purification and partial characterization of the major outer membrane protein of Chlamydia trachomatis. Infect Immun 31:1161- 
1176. (1981)

16. Capparelli R, De Chiara F, Nocerino N, Montella RC, Iannaccone M, Fulgione A Romanelli A, Avitabile C, Blaiotta G, Capuano F. New perspectives for natural antimicrobial peptides: application as antinflammatory drugs in a murine model. BMC Immunol 13:61. (2012)

17. Cole AM, Ganz T, Liese AM, Burdick MD, Liu L, Strieter RM. Cutting edge: IFNinducible ELR-CXC chemokines display defensin-like antimicrobial activity. J. Immunol. 167:623-627. (2001)

18. Crawford MA, Burdick MD, Glomski IJ, Boyer AE, Barr JR, Mehrad B, Strieter RM, Hughes MA. Interferon-inducible CXC chemokines directly contribute to host defense against inhalational anthrax in a murine model of infection. PLoS Pathog. 18;6(11):e1001199. (2010)

19. Crawford MA, Zhu Y, Green CS, Burdick MD, Sanz P, Alem F, O'Brien AD, Mehrad B, Strieter RM, Hughes MA. Antimicrobial effects of interferon-inducible CXC chemokines against Bacillus anthracis spores and bacilli. Infect Immun. 77(4): 1664-78. (2009)

20. Cunningham AF, Ward ME. Characterization of human humoral responses to the major outer membrane protein and OMP2 of Chlamydophila pneumoniae. FEMS Microbiol Lett. 227: 73-79. (2003)

21. Deng JC, Tateda K, Zeng X, Standiford TJ. Transient transgenic expression of gamma interferon promotes Legionella pneumophila clearance in immunocompetent hosts. Infect Immun. 69:6382-6390. (2001)

22. Egesten A, Olin AI, Linge HM, Yadav M, Mörgelin M, Karlsson A, Collin M. SpeB of Streptococcus pyo genes differentially modulates antibacterial and receptor 
activating properties of human chemokines. PLoS One 4:e4769. (2009)

23. Egesten A, Eliasson M, Johansson HM, Olin AI, Morgelin M, Mueller A, Pease JE, Frick IM, Björck L. The CXC chemokine MIG/CXCL9 is important in innate immunity against Streptococcus pyogenes. J Infect Dis. 195:684-693. (2007)

24. Eliasson M, Frick IM, Collin M, Sørensen OE, Björck L, Egesten A.M1 protein of Streptococcus pyo genes increases production of the antibacterial CXC chemokine MIG/CXCL9 in pharyngeal epithelial cells. Microb Pathog. 43:224-233. (2007)

25. Eliasson M, Mörgelin M, Farber JM, Egesten A, Albiger B. Streptococcus pneumoniae induces expression of the antibacterial CXC chemokine MIG/CXCL9 via MyD88dependent signaling in a murine model of airway infection. Microbes Infect. 12(7):56573. (2010)

26. Everett KD, Hatch TP. Architecture of the cell envelope of Chlamydia psittaci 6BC. J Bacteriol. 177:877-882. (1995)

27. Geng Y, Berencsi K, Gyulai Z, Valyi-Nagy T, Gonczol E, Trinchieri G. Roles of interleukin-12 and gamma interferon in murine Chlamydia pneumoniae infection. Infect Immun. 68:2245-2253. (2000)

28. Grayston JT, Campbell LA, Kuo CC, Mordhorst CH, Saikku P, Thom DH, Wang SP. A new respiratory tract pathogen: Chlamydia pneumoniae strain TWAR. J Infect Dis. 161:618-625. (1990)

29. Guaschino S, Ricci G. How, and how efficiently, can we treat Chlamydia trachomatis infections in women? Best Pract Res Clin Obstet Gynaecol. 16(6):875-88. (2002)

30. Hadley EB, Hancock RE. Strategies for the discovery and advancement of novel cationic antimicrobial peptides. Curr Top Med Chem. 10:1872-1881. (2010) 
31. Hafner L, Beagley K, Timms P. Chlamydia trachomatis infection: host immune responses and potential vaccines.Mucosal Immunol. 1(2): 116-30. (2008)

32. Hahn DL, Dodge RW, Golubjatnikov R. Association of Chlamydia pneumoniae (strain TWAR) infection with wheezing, asthmatic bronchitis, and adult-onset asthma. JAMA. 266: 225-230. (1991)

33. Hancock RE, Rozek A. Role of membranes in the activities of antimicrobial cationic peptides. FEMS Microbiol Lett. 206: 143-149. (2002)

34. Handel TM, Johnson Z, Crown SE, Lau EK, Proudfoot AE. Regulation of protein function by glycosaminoglycans--as exemplified by chemokines. Annu Rev Biochem. 74:385-410. (2005)

35. Heltai K, Kis Z, Burian K, Endresz V, Veres A, Ludwig E, Gönczöl E, Valyi-Nagy I. Elevated antibody levels against Chlamydia pneumoniae, human HSP60 and mycobacterial HSP65 are independent risk factors in myocardial infarction and ischaemic heart disease. Atherosclerosis. 173(2):339-46. (2004)

36. Henderson B, Allan E, Coates AR. Stress wars: the direct role of host and bacterial molecular chaperones in bacterial infection. Infect Immun. 74:3693-3706. (2006)

37. Higaki S, Morohashi M. Characteristics of anaerobes from skin specimens. Drugs Exp Clin Res. 29:153-155. (2003)

38. Horner PJ, Cain D, McClure M, Thomas BJ, Gilroy C, Ali M, Weber JN, TaylorRobinson D. Association of antibodies to Chlamydia trachomatis heat-shock protein 60 kD with chronic nongonococcal urethritis. Clin Infect Dis. 24:653-660. (1997) 
39. Howie SEM, Horner PJ, Horne AW, Entrican G. Immunity and vaccines agains sexually transmitted Chlamydia.trachomatis infection. Curr Opin Infect Dis. 24(1): 5661. (2011)

40. Högdahl M, Söderlund G, Kihlström E. Expression of chemokines and adhesion molecules in human coronary artery endothelial cells infected with Chlamydia (Chlamydophila) pneumoniae. APMIS. 116:1082-1088. (2008)

41. Jauregui CE, Wang Q, Wright CJ, Takeuchi H, Uriarte SM, Lamont RJ. Suppression of T-cell chemokines by Porphyromonas gingivalis. Infect Immun. 81(7):2288-95. (2013)

42. Jones RB, Van der Pol B, Martin DH, Shepard MK. Partial characterization of Chlamydia trachomatis isolates resistant to multiple antibiotics. J Infect Dis. 162(6):1309-15. (1990)

43. Kanamoto Y, Ouchi K, Mizui M, Ushio M, Usui T. Prevalence of antibody to Chlamydia pneumoniae TWAR in Japan. J Clin Microbiol. 29:816-818. (1991)

44. Karlsson C, Eliasson M, Olin AI, Mörgelin M, Karlsson A, Malmsten M, Egesten A, Frick IM. SufA of the opportunistic pathogen Fine goldia magna modulates actions of the antibacterial chemokine MIG/CXCL9, promoting bacterial survival during epithelial inflammation. J Biol Chem. 284:29499-29508. (2009)

45. Karlsson C, Andersson ML, Collin M, Schmidtchen A, Björck L, Frick IM. SufA--a novel subtilisin-like serine proteinase of Finegoldia magna. Microbiology. 153(Pt 12):4208-18. (2007)

46. Kis Z, Burían K, Treso B, Acs K, Prohaszka Z, Fust G, Gonczol E, Endresz V. Inflammatory- and immune responses in relation to bacterial replication in mice following re-infections with Chlamydophila pneumoniae. Inflamm Res. 57:287-295. 
(2008)

47. Laemmli UK. Cleavage of structural proteins during the assembly of the head ofbacteriophage, T4. Nature. 227:680-685. (1970)

48. Lauw FN, Simpson AJ, Prins JM, van Deventer SJ, Chaowagul W, White NJ, van der Poll T. The CXC chemokines gamma interferon (IFN-gamma)-inducible protein 10 and monokine induced by IFN-gamma are released during severe melioidosis. Infect Immun. 68:3888-3893. (2000)

49. Lefevre JC, Lepargneur JP, Guion D, Bei S. Tetracycline-resistant Chlamydia trachomatis in Toulouse, France. Pathol Biol (Paris). 45(5):376-8. (1997)

50. Liang YJ, Luo J, Lu Q, Zhou Y, Wu HW, Zheng D, Ren YY, Sun KY, Wang Y, Zhang ZS. Gene profile of chemokines on hepatic stellate cells of schistosomeinfected mice and antifibrotic roles of CXCL9/10 on liver non-parenchymal cells. PLoS One. 7(8):e42490. (2012)

51. Linge HM, Collin M, Giwercman A, Malm J, Bjartell A, Egesten A. The antibacterial chemokine MIG/CXCL9 is constitutively expressed in epithelial cells of the male urogenital tract and is present in seminal plasma. J Interferon Cytokine Res. 28(3):1916. (2008)

52. Maass M, Bartels C, Engel PM, Mamat U, Sievers HH. Endovascular presence of viable Chlamydia pneumoniae is a common phenomenon in coronary artery disease. $\mathrm{J}$ Am Coll Cardiol. 3 1:827-832. (1998)

53. Mahony JB, Luinstra KE, Waner J, McNab G, Hobranzska H, Gregson D, Sellors JW, Chernesky MA. Interlaboratory agreement study of a double set of PCR plasmid primers for detection of Chlamydia trachomatis in a variety of genitourinary specimens. J Clin Microbiol. 32(1):87-91. (1994) 
54. Malek M. Economic implications of Chlamydia trachomatis. In: Moss TR. International handbook of Chlamydia. Exeter, UK: Polestar Wheatons Ltd. (2001)

55. Maxion HK, Kelly KA. Chemokine expression patterns differ within anatomically distinct regions of the genital tract during Chlamydia trachomatis infection. Infect Immun. 70:1538-1546. (2001)

56. Mergaert P, Nikovics K, Kelemen Z, Maunoury N, Vaubert D, Kondorosi A, Kondorosi E. A novel family in Medicago truncatula consisting of more than 300 nodule-specific genes coding for small, secreted polypeptides with conserved cysteine motifs. Plant Physiol 132: 161-173. (2003)

57. Miller ST, Hammerschlag MR, Chirgwin K, Rao SP, Roblin P, Gelling M, Stilerman T, Schachter J, Cassell G. Role of Chlamydia pneumoniae in acute chest syndrome of sickle cell disease. J Pediatr. 118:30-33. (1991)

58. Moelleken K, Hegemann JH. The Chlamydia outer membrane protein OmcB is required for adhesion and exhibits biovar-specific differences in glycosaminoglycan binding. Mol Microbiol. 67:403-419. (2008)

59. Moore TA, Perry ML, Getsoian AG, Newstead MW, Standiford TJ. Divergent role of gamma interferon in a murine model of pulmonary versus systemic Klebsiella pneumoniae infection. Infect Immun. 70:6310-63 18. (2002)

60. Murdoch DA. Gram-positive anaerobic cocci. Clin Microbiol Rev. 11:81-120. (1998)

61. Murray PR, Rosenthal KS, Pfaller MA, Medical Microbiology. P. 441-449. (2009)

62. Nagarajan UM, Prantner D, Sikes JD, Andrews Jr. CW, Goodwin AM, Nagarajan S, Darville T. Type I interferon signaling exacerbates Chlamydia muridarum genital 
infection in a murine model. Infect Immun. 76:4642-4648. (2008)

63. Nallu S, Silverstein KA, Samac DA, Bucciarelli B, Vance CP, VandenBosch KA. Regulatory patterns of a large family of defensin-like genes expressed in nodules of Medicago truncatula. PLoS One 8:e60355. (2013)

64. Nelson S, Mason CM, Kolls J, Summer WR. Pathophysiology of pneumonia. Clin Chest Med. 16:1-12. (1995)

65. Park MK, Amichay D, Love P, Wick E, Liao F, Grinberg A, Rabin RL, Zhang HH, Gebeyehu S, Wright TM, Iwasaki A, Weng Y, DeMartino JA, Elkins KL, Farber JM. The CXC chemokine murine monokine induced by IFN-gamma (CXC chemokine ligand 9) is made by APCs, targets lymphocytes including activated B cells, and supports antibody responses to a bacterial pathogen in vivo. J Immunol. 169(3): 143343. (2002)

66. Penttilä T, Vuola JM, Puurula V, Anttila M, Sarvas M, Rautonen N, Mäkelä PH, Puolakkainen M. Immunity to Chlamydia pneumoniae induced by vaccination with DNA vectors expressing a cytoplasmic protein (Hsp60) or outer membrane proteins (MOMP and Omp2). Vaccine. 19(9-10):1256-65. (2000)

67. Portig I, Goodall JC, Bailey RL, Gaston JS. Characterization of the humoral immune response to Chlamydia outer membrane protein 2 in chlamydial infection. Clin Diagn Lab Immunol. 10:103-107. (2003)

68. Powers JP, Hancock RE. The relationship between peptide structure and antibacterial activity. Peptides. 24:1681-1691. (2003)

69. Randolph AG, Washington AE. Screening for Chlamydia trachomatis in adolescent males: a cost-based decision analysis. Am J Public Health. 80(5):545-50. (1990) 
70. Resnikoff S, Pascolini D, Etya'ale D, Kocur I, Pararajasegaram R, Pokharel GP, Mariotti SP. Global data on visual impairment in the year 2002. Bull World Health Organ. 82(1 1):844-51. (2004)

71. Rigano MM, Romanelli A, Fulgione A, Nocerino N, D'Agostino N, Avitabile C Frusciante L, Barone A, Capuano F, Capparelli R. A novel synthetic peptide from a tomato defensin exhibits antibacterial activities against Helicobacter pylori. J Pept Sci. (2012)

72. Rosenfeld J, Capdevielle J, Guillemot JC, Ferrara P. In-gel digestion of proteins for internal sequence analysis after one- or two-dimensional gel electrophoresis. Anal Biochem. 203:173-179. (1992)

73. Rottenberg ME, Gigliotti-Rothfuchs A, Wigzell H. The role of IFN-gamma in the outcome of chlamydial infection. Curr Opin Immunol. 14:444-451. (2002)

74. Rubins JB, Pomeroy C. Role of gamma interferon in the pathogenesis of bacteremic pneumococcal pneumonia. Infect Immun. 65:2975-2977. (1997)

75. Rugonfalvi-Kiss S, Endrész V, Madsen HO, Burián K, Duba J , Prohászka Z, Karádi I, Romics L, Gönczöl E, Füst G, Garred P. Association of Chlamydia pneumoniae with coronary artery disease and its progression is dependent on the modifying effect of mannose-binding lectin. Circulation. 106(9): 1071-6. (2002)

76. Sahin H, Borkham-Kamphorst E, Kuppe C, Zaldivar MM, Grouls C, Al-samman M, Nellen A, Schmitz P, Heinrichs D, Berres ML, Doleschel D, Scholten D, Weiskirchen R, Moeller MJ, Kies sling F, Trautwein C, Wasmuth HE. Chemokine Cxc19 attenuate liver fibrosis-associated angiogenesis in mice. Hepatology. 55(5): 16 10-9. (2012)

77. Schautteet K, De Clercq E, Vanrompay D. Chlamydia trachomatis vaccine research through the years. Infect Dis Obstet Gynecol. 2011:963513. (2011). 
78. Shaw K, Coleman D, O'Sullivan M, Stephens N. Public health policies and management strategies for genital Chlamydia trachomatis infection. Risk Manag Healthc Policy. 4:57-65. (2011)

79. Shen J, Gao J, Chen C, Lu H, Hu G, Shen J, Zhu S, Wu M, Wang X, Qian L, Yu Y Han W, Wan R, Wang X. Cytokine. Antifibrotic role of chemokine CXCL9 in experimental chronic pancreatitis induced by trinitrobenzene sulfonic acid in rats. 64(1):382-94. (2013)

80. Skwor TA, Atik B, Kandel RP, Adhikari HK, Sharma B, Dean D. Role of secreted conjunctival mucosal cytokine and chemokine proteins in different stages of trachomatous disease. PLoS Negl Trop Dis. 16;2:e264. (2008)

81. Söbirk SK, Mörgelin M, Egesten A, Bates P, Shannon O, Collin M. Human chemokines as antimicrobial peptides with direct parasiticidal effect on Leishmania mexicana in vitro. PLoS One. 8(3):e58 129. (2013)

82. Somani J, Bhullar VB, Workowski KA, Farshy CE, Black CM. Multiple drug-resistant Chlamydia trachomatis associated with clinical treatment failure. $\mathrm{J}$ Infect Dis. 181(4):1421-7. (2000)

83. Stephens RS, Koshiyama K, Lewis E, Kubo A. Heparin-binding outer membrane protein of chlamydiae. Mol Microbiol. 40:691-699. (2001)

84. Stephens RS. The cellular paradigm of chlamydial pathogenesis. Trends Microbiol. $11: 44-51 .(2003)$

85. Thylefors B, Négrel AD, Pararajasegaram R, Dadzie KY. Global data on blindness. Bull World Health Organ. 73:115. (1995) 
86. Tiricz H, Szucs A, Farkas A, Pap B, Lima RM, Mar' ${ }^{\mathrm{y}}$ ti G, Kondorosi É, Kereszt A. Antimicrobial nodule-specific cysteine-rich peptides induce membrane depolarizationassociated changes in the transcriptome of Sinorhizobium meliloti. Appl Environ Microbiol. 79:6737-6746. (2013)

87. Wagels G, Rasmussen S, Timms P. Comparison ofChlamydia pneumoniae isolates by western blot (immunoblot) analysis and DNA sequencing of the omp 2 gene. J Clin Microbiol. 32:2820-2823. (1994)

88. Ward ME. Mechanisms of chlamydia-induced disease. p.171-210. In Stephens RS, ed. Chlamydia: intracellular biology, pathogenesis, and immunity. ASM Press Washington, DC. (1999)

89. Washington AE, Sweet RL, Shafer MA. Pelvic inflammatory disease and its sequelae in adolescents. J Adolesc Health Care. 6(4):298-3 10. Review. (1985)

90. West SK, Muñoz B, Mkocha H, Hsieh YH, Lynch MC. Progression of active trachoma to scarring in a cohort of Tanzanian children. Ophthalmic Epidemiol. 8(2-3):137-44. (2001)

91. WHO: Global Prevalence and Incidence of Selected SexuallyTransmitted Diseases: Overviews and Estimates. Geneva, Switzerland: World Health Organization. (1996)

92. Wang S, Fan Y, Brunham RC, Yang X. IFN-gamma knockout mice show Th2associated delayed-type hypersensitivity and the inflammatory cells fail to localize and control chlamydial infection. Eur JImmunol. 29:3782-3792. (1999)

93. Watson MW, PR Lambden, JS Everson, IN Clarke. Immunoreactivity of the $60 \mathrm{kDa}$ cysteine-rich proteins of Chlamydia trachomati, Chlamydia psittaci and Chlamydia pneumoniae expressed in Escherichia coli. Microbiology. 140:2003-2011. (1994) 
94. Whittington WL, Kent C, Kissinger P, Oh MK, Fortenberry JD, Hillis SE, Litchfield B, Bolan GA, St Louis ME, Farley TA, Handsfield HH. Determinants of persisten and recurrent Chlamydia trachomatis infection in young women: results of a multicenter cohort study. Sex Transm Dis. 28(2): 117-23. (2001)

95. Wright HR, Turner A, Taylor HR. Trachoma. Lancet.7;371(9628):1945-54. (2008)

96. Wuppermann FN, Mölleken K, Julien M, Jantos CA, Hegemann JH. Chlamydia pneumoniae GroEL1 protein is cell surface associated and required for infection of HEp-2 cells. J Bacteriol. 190:3757-3767. (2008)

97. Zügel U, Kaufmann SH. Role of heat shock proteins in protection from and pathogenesis of infectious diseases. Clin Microbiol Rev. 12:19-39. (1999) 
12. Annexes 


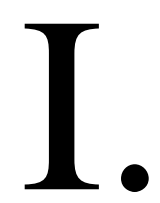


II. 